Canadian

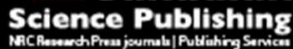

Canadian Geotechnical Journal Revue canadienne de géotechnique

Multi-scale Laboratory Evaluation of the Physical, Mechanical and Microstructural Properties of Soft Highway Subgrade Soil Stabilized with Calcium Carbide Residue

\begin{tabular}{|r|l|}
\hline Journal: & Canadian Geotechnical Journal \\
\hline Manuscript ID & cgj-2015-0245.R1 \\
\hline Manuscript Type: & Article \\
\hline Date Submitted by the Author: & 13 -Aug-2015 \\
\hline Complete List of Authors: & $\begin{array}{l}\text { Jiang, Ning-Jun; University of Cambridge, Department of Engineering } \\
\text { Du, Yan-Jun; Southeast University, Institute of Geotechnical Engineering } \\
\text { Liu, Songyu; Southeast University, Institute of Geotechnical Engineering } \\
\text { Wei, Ming-Li; Southeast University, Institute of Geotechnical Engineering } \\
\text { Horpibulsuk, Suksun; Suranaree University of Technology, Civil } \\
\text { Engineering } \\
\text { Arulrajah, Arul; Swinburne University of Technology }\end{array}$ \\
\hline Keyword: & calcium carbide residue, multi-scale, pozzolanic reaction, soil stabilization \\
\hline & \multicolumn{2}{|c}{} \\
\hline
\end{tabular}




\section{Multi-scale Laboratory Evaluation of the Physical, Mechanical and Microstructural Properties of Soft Highway Subgrade Soil Stabilized with Calcium Carbide Residue}

Ning-Jun Jiang

$\mathrm{PhD}$ candidate, Department of Engineering, University of Cambridge, UK. Formerly, PhD student in Institute of Geotechnical Engineering, Southeast University, China.

\section{Yan-Jun Du *}

Professor, Institute of Geotechnical Engineering, Southeast University, Nanjing 210096, China (*Corresponding author. PH/FAX: 86-25-83795086, E-mail: duyanjun@ seu.edu.cn)

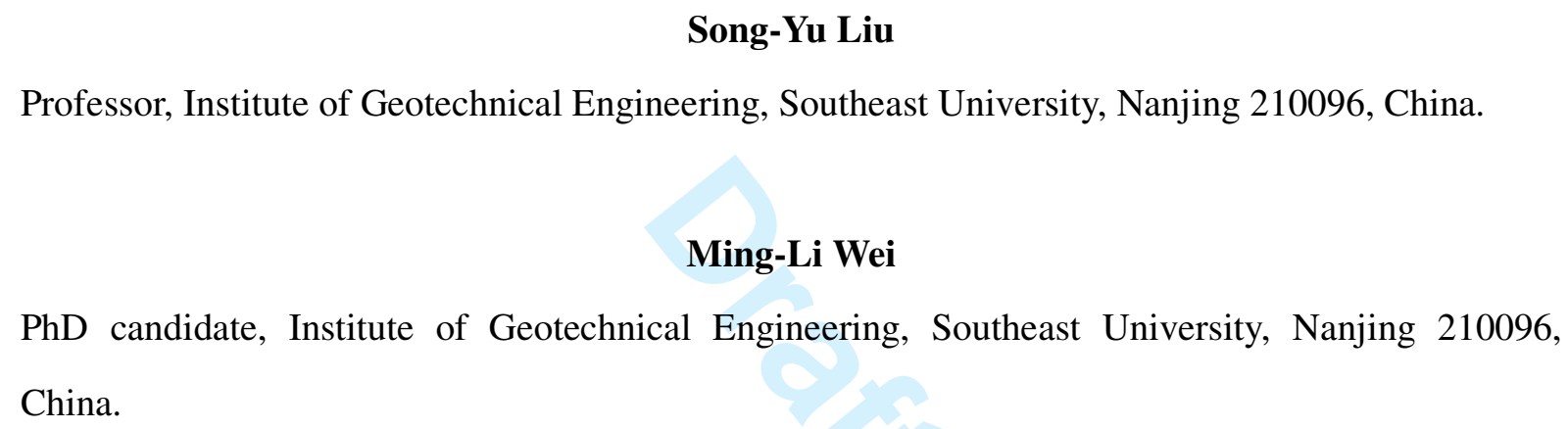

\section{Ming-Li Wei}

PhD candidate, Institute of Geotechnical Engineering, Southeast University, Nanjing 210096, China.

\section{Suksun Horpibulsuk}

Professor, School of Civil Engineering, Suranaree University of Technology, Nakhon Ratchasima 30000, Thailand.

\author{
Arul Arulrajah \\ Professor, Centre for Sustainable Infrastructure, Swinburne University of Technology, Victoria 3122, \\ Australia. \\ A Research Article Submitted for Possible Publication in \\ Canadian Geotechnical Journal
}


Abstract: Calcium carbide residue (CCR) is an industrial by-product, stockpiles of which are rapidly accumulating worldwide. Highway embankment construction has been identified as an avenue to consume huge quantities of $\mathrm{CCR}$ as an economical, less energy intensive and environmental-friendly chemical additive for soil stabilization. Previous studies have investigated the mechanical behavior of soils stabilized by CCR or blends of CCR with other additives; however, interpretation of the macro-scale geomechanical behavior of CCR stabilized soft soils from a systematically microstructural observation and analysis is relatively unknown. This paper presents a multi-scale laboratory investigation on the physical, mechanical and microstructural properties of CCR stabilized clayey soils with comparison to quicklime stabilized soils. Several series of tests were conducted to examine the Atterberg limits, particle size distribution, compaction characteristics, unconfined compressive strength, California-Bearing-Ratio and resilient modulus of the CCR stabilized clayey soils. The influences of binder content, curing time, and initial compaction state on the physical and mechanical properties of treated soils are interpreted with the aids of physicochemical and microstructural observations including soil $\mathrm{pH}$, soil mineralogy obtained from X-ray diffraction and thermogravimetric analysis, and pore size distribution obtained from mercury intrusion porosimetry. Soil particle flocculation and agglomeration at the early stage and pozzolanic reactions during the entire curing time, which originate from the finer particle size, greater specific surface area and higher $\mathrm{pH}$ value of calcium carbide residue, are the controlling mechanisms for the superior mechanical performance of CCR stabilized soils. The outcomes of this research will contribute to the usage of CCR as a sustainable and alternative stabilizer to quicklime in highway embankment applications.

Key Words: calcium carbide residue; multi-scale; pozzolanic reaction; soil stabilization 


\section{Introduction}

Calcium carbide residue (CCR) is a by-product of polyvinyl chloride (PVC), polyvinyl alcohol and acetylene production. CCR is formed through the hydrolysis of calcium carbide, as shown by the following equation (Jaturapitakkul and Roongreung 2003):

$$
\mathrm{CaC}_{2}+2 \mathrm{H}_{2} \mathrm{O}=\mathrm{C}_{2} \mathrm{H}_{2}+\mathrm{Ca}(\mathrm{OH})_{2}
$$

The dominant component of $\mathrm{CCR}$ is $\mathrm{Ca}(\mathrm{OH})_{2}$, with limited amounts of calcium carbonate $\left(\mathrm{CaCO}_{3}\right), \mathrm{SiO}_{2}$, and trace components of sulfide, metal oxide and organic matters (Kampala and Horpibulsuk 2013). CCR is presently widespread in developing and developed countries alike (Sharma and Reddy 2004; Du et al. 2011, 2015a; Horpibulsuk et al. 2013b; Phetchuay et al. 2014). CCR usually appears as high-alkaline and high-moisture-content slurry. If not handled properly, CCR becomes a source of pollution to surface and underground water (Krammart and Tangtermsirikul 2004; Sharma and Reddy 2004). In recent years, the increasingly large production quantity of CCR due to growing demand has often resulted in serious environmental pollution with stockpile areas (Du et al. 2011). Reuse applications for CCR, particularly in large civil engineering infrastructure applications that can rapidly deplete these growing stockpiles, are urgently being sought. The usage of CCR as a sustainable cementitious binder for soil stabilization has been identified as a low-carbon and less energy intensive means to reuse this by-product and furthermore eliminate negative environmental connotations associated with stockpiling this by-product. Similar approaches have been successfully attempted in recent years for other geomaterials including geopolymer, phosphate-rich materials and demolition aggregates (Du et al. 2011, 2014b; Horpibulsuk et al. 2013b, 2014; Sukmak et al. 2013a, b, 2015; Arulrajah et al. 2014; Cai et al. 2015).

Soft clay deposits, which are widely distributed in East China regions, impose great challenges in the construction of infrastructure projects such as highway embankments (Liu et al. 2011; 
Horpibulsuk et al. 2013b). These soft clay deposits are typically of low strength, low stiffness and low permeability, making them difficult to improve and compact. These difficulties often result in the highway embankments having low bearing capacity and furthermore susceptible to excessive settlements (Kodikara and Chakrabarti 2005; Chakrabarti and Kodikara 2007; Han et al. 2007; Gnanendran and Piratheepan 2010). Chemical stabilization is an effective method to improve the engineering properties of soft clayey soils (Shen et al. 2013). Huge amount of chemical additives are needed to stabilize the soft soils in-situ, given that the geometries of typical embankments are of large lengths and widths. The large-scale quantities of CCR by-products generated in Eastern China, creates the opportunity for the recycling of this industrial by-product in the construction of highway embankment (Du et al. 2011), particularly as soft soil deposits are largely prevalent in this region. The reuse of CCR in highway embankment construction is cost-economic and has no extra associated embedded energy consumption compared to conventional cement-based binders, making it an attracting alternative for project contractors and constructors (Horpibulsuk et al. 2012, 2013a; Du et al. 2015a). Similar to other chemical additives (e.g., Portland cement, fly ash and slag) for soft clay stabilization (Jin and Al-Tabbaa 2014; Du et al. 2015b), CCR is mixed with the parent soft clayey soil and reacts with clay minerals and water to improve the strength, stiffness and durability of the stabilized soil (Kampala and Horpibulsuk 2013; Du et al. 2011).

Previous studies focused on the use of CCR alone or the blend of CCR and other chemical additives in soft soils stabilization. For example, Kampala and Horpibulsuk (2013) examined the physical and engineering properties of a problematic silty clay stabilized with CCR and stated that CCR was more effective than lime in soft soil stabilization in terms of engineering, economic, and environmental perspectives. Horpibulsuk et al. (2013a) investigated the strength characteristics of a silty soil treated by the blend of CCR and fly ash and proposed a controlling strength development 
101

102

103

104

105

106

107

108

109

110

111

112

113

114

115

116

117

mechanism based on different strength improvement zones. Vichan and Rachan (2013) systematically investigated the strength development patterns of the soft Bangkok clay stabilized by blends of CCR and biomass ash, and reported that the properties of both materials significantly affected the strength gains. Phetchuay et al. (2014) used CCR- alkali activated stabilized clay geopolymer as a sustainable pavement subgrade material and examined the influential factors for strength development. Most of these existing studies focused on the examination of engineering properties and associated influential factors affecting the strength of soils stabilized by CCR alone or with blends of CCR and other additives. The interpretation of macro-scale geomechanical behaviors of CCR stabilized soft soils from a systematically microstructural observation and analysis is however relatively unknown. Microstructural analytical methods in geotechnical engineering typically include X-ray diffraction (XRD), scanning electron microscopy (SEM), mercury intrusion porosimetry (MIP) and thermogravimetric analysis (TGA) (Mitchell and Soga 2005). These methods have been extensively employed to produce explicit microstructural supporting evidences for the hypothesis explaining geomechanical behaviors of soft soils or aggregates stabilized by conventional chemical additives (e.g., Portland cement and lime) (Locat et al. 1996; Al-Mukhtar et al. 2010; Stoltz et al. 2012; Du et al. 2014a; Mohammadinia et al. 2014;). For example, Wild et al. (1993) employed the XRD, SEM-EDAX and thermal analysis to investigate the chemical, morphological and microstructural changes occurring during moist curing and soaking of lime stabilized kaolinite. Lemaire et al. (2013) carried out a multi-scale studies of the cement-lime stabilized plastic silty soil and interpreted the mechanical properties from the physicochemical and microstructural perspective using SEM, XRD, and MIP. Similarly, multi-scale observations and analysis would be helpful to understanding the controlling mechanisms of soft clay stabilization by CCR. 
This paper presents a multi-scale laboratory evaluation of the physical, mechanical and microstructural properties of CCR stabilized soft clayey soil. Several macro-scale series of tests were conducted to examine the Atterberg limits, particle size distribution (PSD), compaction characteristics, unconfined compressive strength $\left(q_{\mathrm{u}}\right)$, California-Bearing-Ratio $(\mathrm{CBR})$ and resilient modulus $\left(M_{\mathrm{r}}\right)$ of the CCR stabilized clayey soils. Quicklime, which is used extensively in stabilizing highway subgrade materials, is selected as a control chemical additive for comparison purposes. The influences of binder content, curing time, and initial compaction state on the physical and mechanical properties of stabilized soils are interpreted with the aids of physicochemical and microstructural observations including the soil $\mathrm{pH}$, soil mineralogy obtained from XRD and thermogravimetric analysis (TGA), and pore size distribution obtained from mercury intrusion porosimetry (MIP) analysis.

\section{Materials and Methods}

\section{Soils and binders}

The soil used in this study was excavated from the site of West Changzhou Ring Expressway located in Changzhou City, Jiangsu Province, China. The basic physical and engineering properties of the soil are listed in Table 1. The soil is classified as a low plasticity clay (CL) based on ASTM D2487 (ASTM 2011a). The result of X-ray fluorescence (XRF) analysis of the parent soil indicates that it contains $67.9 \%$ of silicon dioxide $\left(\mathrm{SiO}_{2}\right), 14.1 \%$ of aluminum oxide $\left(\mathrm{Al}_{2} \mathrm{O}_{3}\right), 5 \%$ of ferric oxide $\left(\mathrm{Fe}_{2} \mathrm{O}_{3}\right), 2.5 \%$ of magnesium oxide $(\mathrm{MgO})$, and $1.3 \%$ of calcium oxide $(\mathrm{CaO})$ (see Table 2). The particle size distribution curve of the parent soil is shown in Fig. 1.

CCR used in this study was collected from Jiangsu Changzhou Changfei Acetylene Manufacturing Co. Ltd. Its basic physical and chemical characteristics are listed in Table $\mathbf{3}$ and its major chemical constituents are shown in Table 2. The CCR was air-dried prior to the specimen 
preparation for various laboratory-scale tests due to its natural moisture content up to $60.9 \%$.

Quicklime used in this laboratory test was produced by Liyang Shanghuang Yangzhu Tianfu Lime Manufacturing Station. Basic physical and chemical characteristics of the quicklime are listed in

Table 3 and its major chemical constituents are presented in Table 2. This quicklime is classified as High-Calcium Lime based on ASTM C51-11 (ASTM 2011b). The particle size distribution curves of the CCR and quicklime are shown in Fig. 1.

\section{Sample preparation}

Prior to the series of test in this study, the standard Proctor compaction test were conducted to obtain the maximum dry density $\left(\rho_{\mathrm{dmax}}\right)$ and optimum water content $\left(w_{\mathrm{opt}}\right)$ of binder-amended soils right after mixture. For Atterberg limits and particle size distribution (PSD) tests, collected soils were air-dried before they were passed through the sieve with $0.5 \mathrm{~mm}$ opening size. Then, the air-dried soils were thoroughly mixed with predetermined amount of binders (i.e. CCR or quicklime) and water (approximately $w_{\text {opt }}$ ). The binder-amended soils were then cured in sealed vinyl bags at $20^{\circ} \mathrm{C}$ and relative humidity of $95 \%$ for $28 \mathrm{~d}$ before subjected to the Atterberg limits and PSD tests.

For other tests in this study, the air-dried soils were firstly prepared with predetermined amount of binders (i.e. CCR or quicklime) and water (approximately $w_{\text {opt }}$ ) in cylindrical iron molds (Ф152 $\times \mathrm{H} 170 \mathrm{~mm}$ for CBR and $M_{\mathrm{r}}$ tests, and $\Phi 50 \times \mathrm{H} 50 \mathrm{~mm}$ for unconfined compression test; soils for $\mathrm{pH}$, TGA and MIP tests were sampled from the $\Phi 50 \times \mathrm{H} 50 \mathrm{~mm}$ sample) via the static compaction method to achieve degree of compaction of $93 \%, 94 \%$ and $96 \%$. All inner walls of molds were lubricated with Vaseline to reduce friction. All samples were subsequently cured at $20^{\circ} \mathrm{C}$ and relative humidity of $95 \%$ for 7 and 28 d, respectively, before testing. Table 4 presents the binder dosage, curing time, degree of compaction, and the number of identical samples for different tests in 
171 this study. For unconfined compression, CBR, resilient modulus, and TGA tests, three identical

172 samples were tested. The coefficient of variation (COV) for the results of unconfined compression

173 test, CBR and resilient modulus tests are less than $8 \%$ and COV for TGA test is less than $4 \%$,

174 indicating excellent repeatability of the test results.

175

176

177

178

179

180

181

182

183

184

185

186

187

188

189

190

191

192

193

\section{Testing methods}

Atterberg limits were conducted according to ASTM D 4318 (ASTM 2010). PSD tests for the parent soil, CCR, quicklime, and CCR and quicklime stabilized soils were conducted using a Mastersizer 2000 laser particle size analyzer (Malvern Inc., U.K.). Prior to PSD analysis, both stabilized and unstabilized soil specimens were air-dried and grinded through a $0.3 \mathrm{~mm}$ sieve. Then, $15 \mathrm{~g}$ grinded specimen was mixed with sufficient distilled water and subjected to the PSD analysis. Standard Proctor compaction test was conducted with a standard compaction effect of $600 \mathrm{kN}-\mathrm{m} / \mathrm{m}^{3}$ as per ASTM D 698 (ASTM 2012). The unconfined compression test was performed based on ASTM D4219 (ASTM 2008). The rate of vertical load remained $1 \mathrm{~mm} / \mathrm{min}$ until the failure of the specimen. It should be noted that the specimen size in this study $(\Phi 50 \times \mathrm{H} 50 \mathrm{~mm})$ is slightly difference from the length-to-diameter ratio (2.5) recommended by ASTM D 4219. The CBR test was conducted according to ASTM D 1883 (ASTM 2014). A circular piston was used to intrude stabilized soils in a mold at a constant rate of penetration. The CBR was determined as the ratio of the unit load on the piston required to penetrate $2.5 \mathrm{~mm}$ or $5 \mathrm{~mm}$ of the test soil to the unit load required to penetrate a standard material of well-graded crushed stone. Resilient modulus test was conducted as per AASHTO T307 (AASHTO 2007), which was also previously adopted by Tastan et al. (2011). The specimen size in this study $(\Phi 152 \times \mathrm{H} 170 \mathrm{~mm})$ is modified from that in AASHTO T307 $(\Phi 102 \times \mathrm{H} 203 \mathrm{~mm}) . M_{\mathrm{r}}$ was calculated based on the ratio of deviator stress and the 
recoverable strain. Different confining and deviator stresses were applied on the specimens to cover the range of expected stresses in the field.

Physicochemical and microstructural observational tests conducted in this study include soil $\mathrm{pH}, \mathrm{XRD}$, TGA and MIP. Soil $\mathrm{pH}$ measurement was carried out using a HORIBA pH/COND METER D-54 as per ASTM D4972 (ASTM 2013). Both stabilized and unstabilized soils were grinded through a sieve with $2 \mathrm{~mm}$ opening size. The liquid to solid ratio of 1.0 was used to mix the soil and distilled water. The $\mathrm{pH}$ of the slurry was then measured after $1 \mathrm{hr}$ of retention. In order to examine the chemical and mineralogical compositions of CCR and quicklime stabilized soils, XRD test was conducted for stabilized soils with $6 \%$ binder content at $180 \mathrm{~d}$. As a reference, unstabilized soil was also subjected to the XRD test. The XRD tests were performed using a Rigaku D/Max-2500 X-ray diffractometer. $\mathrm{Cu}-K \alpha(\lambda=1.540538 \AA)$ X-ray tube with an input voltage of 40 $\mathrm{kV}$ and a current of $200 \mathrm{~mA}$ was utilized. Prior to the test, both stabilized and unstabilized soil specimens were freeze-dried and then grinded into a sieve with $0.038 \mathrm{~mm}$ opening size. The tests were carried out between two-theta values of 5 to $60^{\circ}$ with a step length of $0.02^{\circ}$ and a scanning rate of $2 \% \mathrm{~min}$.

Thermogravimetric analyses (TGA) was conducted by heating a test specimen continuously from room temperature to $750^{\circ} \mathrm{C}$ at a heating rate of $20^{\circ} \mathrm{C} / \mathrm{min}$ in a nitrogen environment. In this study, TGA was performed using a differential scanning calorimeter (Perkin-Elmer Pyris 1). After designated curing periods of 28 and $120 \mathrm{~d}, 3$ identical cubic samples $(1 \mathrm{~cm} \times 1 \mathrm{~cm})$ were extracted and soaked in absolute ethyl alcohol for $96 \mathrm{hr}$ to terminate the hydration. The specimens were then dried at $30{ }^{\circ} \mathrm{C}$ and grinded through a 200 -mesh sieve. Approximate $30 \pm 0.5 \mathrm{mg}$ sieved specimens were used for the TGA test. The results of TGA are presented as a curve of the mass loss versus temperature. The first derivative of the mass loss curve is recorded as a function of time, which is 
217

218

219

220

221

222

223

224

225

226

227

228

229

230

231

232

233

234

235

236

237

238

239

known as derivative thermogravimetric analysis (DTG).

The MIP test is based on the fact that mercury is a non-wetting fluid that has to be pressurized in order to penetrate a porous medium (Diamond 1970). In this method, all pores are considered to be of cylindrical shape and therefore the Jurin's equation which calculates capillary pressure can be applied in MIP method:

$$
d=-\frac{4 \tau \cos \theta}{p}
$$

where $d$ is the diameter of the pore intruded, $\tau$ is the surface tension of intruded liquid (i.e. mercury), $\theta$ is the contact angle, and $p$ is the applied pressure. In this study, MIP test was carried out using an AutoPore IV 9510 mercury intrusion porosimeter (Micromeritics Co. Ltd. USA). The maximum applied pressure is $6 \times 10^{4}$ psi (i.e. $413 \mathrm{MPa}$ ) and the surface tension of mercury is $4.84 \times 10^{-4}$ $\mathrm{N} / \mathrm{mm}$ at $25^{\circ} \mathrm{C}$ (Mitchell and Soga 2005). The contact angle is taken as $135^{\circ}$. After curing periods, stabilized soil specimens were broken up to about $1 \mathrm{~cm} \times 1 \mathrm{~cm}$ cubes in a careful manner to eliminate disturbance. Liquid nitrogen was used to freeze the soil specimens, after which the specimens were placed in a freezing unit with a vacuum chamber, and were dried by sublimation of the frozen water at a temperature of $-80^{\circ} \mathrm{C}$. (Penumadu and Dean 2000; Li and Zhang 2009).

\section{Results and Analysis}

\section{Atterberg limits}

The results of Atterberg limits tests are shown in Table 5. It is found that both liquid limit $\left(w_{\mathrm{L}}\right)$ and plastic limit $\left(w_{\mathrm{p}}\right)$ of CCR and quicklime stabilized soils are higher than those of unstabilized soils, regardless of binder dosage. In contrast, plastic index $\left(I_{p}=w_{\mathrm{L}}-w_{\mathrm{p}}\right)$ values of both CCR and quicklime stabilized soils decrease by approximate $15 \%$ as compared to those of unstabilized soils.

Kinuthia (1999) and Du et al. (2014a) indicated that formations of flocculate and agglomerate 
(short-term), and pozzolanic reactions (long-term) in lime stabilized soils were able to remarkably modify $w_{\mathrm{L}}$ and $w_{\mathrm{p}}$. Due to the similarity in chemical components between CCR and quicklime, the mechanism proposed by Kinuthia (1999) can explain the variations of Atterberg limits of both CCR and quicklime stabilized soil with binder content and curing time in this study. The decrease in $I_{p}$ values with amendment of CCR or quicklime observed in this study is consistent with those examined by previous studies (Locat et al. 1996; Du et al. 1999) which found that the addition of chemical additives (such as lime) could result in an increase in both $w_{\mathrm{L}}$ and $w_{\mathrm{p}}$ but a reduction in $I_{p}$.

\section{Particle size distribution (PSD)}

The results of PSD test is shown in Table 6. After $28 \mathrm{~d}$ curing time, the addition of $4 \%$ and $6 \%$ CCR leads to reduction of clay-sized particle percentage from $13.6 \%$ to $7.0 \%$ and to $3.8 \%$, respectively, which are higher than the cases of quicklime addition (from $13.6 \%$ to $10.0 \%$ and to $8.2 \%$, respectively). The sand-sized particle percentage of CCR and quicklime stabilized soils increase substantially from $2.5 \%$ to $37.8 \%$ and to 60.7 for $4 \%$ and $6 \%$ CCR, as well as from $2.5 \%$ to $26.4 \%$ and to $26.7 \%$ for $4 \%$ and $6 \%$ quicklime, respectively. The changes in clay- and sand-sized particle percentages in the stabilized soils are dominantly attributed to both short-term flocculation formation and long-term pozzolanic reactions (Nalbantoglu and Tuncer 2001; Tran et al. 2014). The flocculation contributes to agglomeration of fine particles (Nalbantoglu and Tuncer 2001; Kampala et al. 2013) and the synthesized pozzolanic products would coat the surface of soil particles (Tran et al. 2014), both making relatively high fraction of coarse-grained particles.

In comparison with quicklime, CCR stabilized soils exhibit $143 \%$ to $228 \%$ higher sand-sized particle percentage after curing for $28 \mathrm{~d}$. The clay-sized particle percentages of CCR stabilized soils are $29 \%$ to $54 \%$ less than quicklime stabilized soils at $28 \mathrm{~d}$, respectively. The observations suggest 
that CCR yields a superior capability for modifying particle size distribution of the soils as compared to the quicklime.

\section{Compaction characteristics}

The results of standard compaction test show that when the binder content increases from 4 to $6 \%, w_{\mathrm{op}}$ slightly changes from 13.4 to $14.1 \%$ for CCR and from 13.2 to $13.4 \%$ for quicklime, respectively. In contrast, $\rho_{\mathrm{dmax}}$ reduces from 1.78 to $1.74 \mathrm{~g} / \mathrm{cm}^{3}$ and from 1.73 to $1.70 \mathrm{~g} / \mathrm{cm}^{3}$ for CCR and quicklime stabilized soils, respectively, as a consequence of increase in the binder content from 4 to 6\%. The phenomena are consistent with those reported by Fahoum et al. (1996), who also observed the reduction of $\rho_{\mathrm{dmax}}$ with increasing lime content for cohesive soils, and Kampala and Horpibulsuk (2013), who reported the reduction of $\rho_{\mathrm{dmax}}$ with increasing CCR content for silty clay. The reason of the phenomena is predominantly attributed to the flocculation and agglomeration, as a consequence of cation exchange, resulting in material bulking (Kinuthia et al. 1999). The $\rho_{\mathrm{dmax}}$ values of the CCR stabilized soil are always higher than those of quicklime stabilized soils at the binder contents of 4 and $6 \%$, indicating that CCR stabilized soil can achieve a better compaction performance relative to the quicklime with the same dosage.

\section{Unconfined compressive strength}

Figure 2 shows the effects of curing time, degree of compaction and binder content on the $q_{\mathrm{u}}$ of CCR and quicklime stabilized soils. The $q_{\mathrm{u}}$ of unstabilized soils is also marked in Fig. 2 for comparison. It can be noticed that $q_{\mathrm{u}}$ keeps increasing steadily with curing time, irrespective of the degree of compaction and binder content for both stabilized soils. More specifically, the CCR stabilized soil exhibits notable strength development at the initial $60 \mathrm{~d}$ than the subsequent $60 \mathrm{~d}$, 
regardless of the degree of compaction. However, the quicklime stabilized soil gains predominant strength at the initial 30 d with 94 and 96\% degree of compaction. With 93\% degree of compaction, the predominant strength development occurs at the initial $60 \mathrm{~d}$. Moreover, it is evident that higher content of CCR or quicklime results in higher $q_{\mathrm{u}}$ values for all the curing times tested. At the same binder content, the $q_{\mathrm{u}}$ values of CCR stabilized soil are higher than those of the quicklime stabilized soil regardless of the curing time and degree of compaction. The strength development for CCR and quicklime stabilized soft clayey soils in this study is consistent with that reported by Kampala and Horpibulsuk (2013). The strength growth at early stage is attributable to the flocculation and agglomeration of the soil particles (Kinuthia et al. 1999) while the long-term strength development is determined by the pozzolanic reactions (Wild et al., 1993).

CCR and quicklime stabilized soils have a discrepancy in the effect of degree of compaction on the strength development. The $q_{\mathrm{u}}$ values at $120 \mathrm{~d}$ for CCR stabilized soils are around $2250 \mathrm{kPa}$ regardless of the degree of compaction. In contrast, dependence of $q_{\mathrm{u}}$ on the initial compaction state is noticeable for quicklime stabilized soils cured for $120 \mathrm{~d}$. For example, in the case of $6 \%$ amendment, the $q_{\mathrm{u}}$ values at $120 \mathrm{~d}$ are 1600 and $2200 \mathrm{kPa}$ for $93 \%$ and $96 \%$ degree of compaction, respectively. Le Runigo et al. (2009) stated that the impact of compaction energy on the pore size distribution of quicklime stabilized silty soil is margin, indicating a similar soil fabric even under different degree of compaction conditions. However, Osinubi (1998) showed that higher compaction energy was related to higher $q_{\mathrm{u}}$ values for lime stabilized soils, which is consistent with the results of quicklime stabilized soil tested in this study. Since the binder contents adopted in this study are not higher than $6 \%$, the CCR stabilized soils are in the active zone, as suggested by Horpibulsuk et al. (2013). In contrast, the quicklime stabilized soils are in the inert or deterioration zone as suggested by Bell (1996). In the active zone, the long-term $q_{\mathrm{u}}$ of the CCR stabilized soil 
increases with increasing binder content, which is due to the fact that all input portlandite is consumed through pozzolanic reactions (Horpibulsuk et al. 2013). However, in the inert or deterioration zone, the $q_{\mathrm{u}}$ of the quicklime stabilized soil ceases to increase or decrease with increasing binder content, which is caused by internal-structure damage due to presence of excessive free lime (Horpibulsuk et al. 2013). Therefore, when the stabilized soils are in different zones (i.e., active zone and inert or deterioration zone), the effect of degree of compaction on their $q_{\mathrm{u}}$ would be different. This may explain the discrepancy between CCR and stabilized soils in terms of the effect of degree of compaction on the $q_{\mathrm{u}}$.

\section{California Bearing Ratio (CBR)}

Figure 3 presents the effects of curing time, binder content on CBR values with various degree of compaction. The CBR values of both CCR and quicklime stabilized soils are dramatically higher than that of the unstabilized soil, and they increase steadily with increasing curing time, due to the flocculation and agglomeration of soil particles at early stage and pozzolanic reactions at long term (Kinuthia et al. 1999). The CBR values of both CCR and quicklime stabilized soils increase with increasing degree of compaction, which is consistent with that reported by Osinubi (1998). In contrast, the binder content affects CBR values in a different manner for CCR and quicklime stabilized soils. The CBR values of CCR stabilized soils at two binder contents (4 and 6\%) are practically the same, while the quicklime stabilized soil exhibits approximate $30 \%$ increase in the CBR when the binder content increases from $4 \%$ to $6 \%$.

Similar to the unconfined compression test results, the CCR stabilized soils possess much higher CBR values relative to the quicklime stabilized soils, regardless of the binder content, curing time and degree of compaction within the considered range. This result is consistent with that 
obtained from the full-scale field trial tests (Du et al. 2015a), confirming that the CCR stabilization brings higher bearing capacity for the highway soft clayey soils relative to the quicklime. In addition, the measured CBR values also satisfies the requirement specified by the China highway construction standard (CBR $\geq 8 \%$ ) (China MOT 2004).

\section{Resilient modulus $\left(M_{r}\right)$}

Figure 4 illustrates the development of $M_{r}$ for CCR and quicklime stabilized soils with curing time and degree of compaction. It is evident that CCR and quicklime stabilization leads to a significant increase in $M_{r}$, as compared to the unstabilized soil. The $M_{r}$ values of both CCR and quicklime stabilized soils at $28 \mathrm{~d}$ are approximately two times those at $7 \mathrm{~d}$. Elevation of degree of compaction from $94 \%$ to $96 \%$ results in approximate $20 \%$ increase in $M_{r}$ for the CCR stabilized soil, whereas only marginal increase in $M_{r}$ for the quicklime stabilized soil. The change of $M_{r}$ with curing time and degree of compaction is similar to that of $q_{\mathrm{u}}$ (see Fig. 2) and CBR (see Fig. 3).

The $M_{r}$ values of the CCR stabilized soils are found to be remarkably larger than those of quicklime stabilized soils. At $7 \mathrm{~d}$, the $M_{r}$ values of CCR stabilized soils with degree of compaction of $94 \%$ and $96 \%$ are $15 \%$ and $29 \%$, respectively, higher than those of quicklime stabilized soils. This difference increases to $31 \%$ and $44 \%$ at $28 \mathrm{~d}$ for the degrees of compaction of $94 \%$ and $96 \%$, respectively.

\section{Soil pH}

Figure 5 shows the changes in measured soil $\mathrm{pH}$ values of CCR and quicklime stabilized soils with the curing time. It is found that $\mathrm{pH}$ values of both $\mathrm{CCR}$ and quicklime stabilized soils decrease gradually with increasing curing time, which is attributed to the pozzolanic reactions between 
355

356

357

358

359

360

361

362

363

364

365

366

367

368

369

370

371

372

373

374

375

376

377

portlandite $\left(\mathrm{Ca}(\mathrm{OH})_{2}\right)$ and reactive $\mathrm{SiO}_{2} / \mathrm{Al}_{2} \mathrm{O}_{3}$ in the soil matrix expressed by the following equation (Kinuthia et al. 1999):

$$
\mathrm{Ca}(\mathrm{OH})_{2}+\mathrm{SiO}_{2}+\mathrm{H}_{2} \mathrm{O} \rightarrow \mathrm{C}-\mathrm{S}-\mathrm{H}
$$

$$
\mathrm{Ca}(\mathrm{OH})_{2}+\mathrm{Al}_{2} \mathrm{O}_{3}+\mathrm{H}_{2} \mathrm{O} \rightarrow \mathrm{C}-\mathrm{A}-\mathrm{S}-\mathrm{H}
$$

During the pozzolanic reactions, alkaline portlandite is gradually consumed and transformed to less alkaline secondary cementitious products (e.g., C-S-H and C-A-S-H), leading to reduction in soil pH (Kinuthia et al. 1999; Al-Mukhtar et al. 2010; Du et al. 2014a). It is noted that when pH of stabilized soils is higher than 10 to 11 , the reactive $\mathrm{SiO}_{2} / \mathrm{Al}_{2} \mathrm{O}_{3}$ in soil matrix would keep dissolving (Saride et al. 2010) while the formed secondary cementitious products are still thermodynamically stable (Stronach and Glasser 1997). Moreover, the $\mathrm{pH}$ of the CCR stabilized soil is higher than that of the quicklime stabilized one during the entire curing period. This is mainly due to the higher $\mathrm{pH}$ of CCR (12.84) than that of quicklime (12.74), as shown in Table 3.

\section{X-Ray diffraction (XRD)}

Figure 6 presents the XRD diffractograms of the stabilized and unstabilized soils. The minerals in the unstabilized soil are predominantly quartz, kaolinite and illite with trace montmorillonite. For the CCR stabilized soil, formation of C-S-H is detected at $2 \theta$ of $27.5^{\circ}, 28.3^{\circ}, 52.9^{\circ}$ and $54.5^{\circ}$, respectively. In contrast, no distinct peaks for portlandite are identified in the CCR stabilized soil. As C-S-H is the secondary cementitious products (see Eqs. (3) and (4)) formed in the pozzolanic reactions, the identified peaks of C-S-H and absence of portlandite in the CCR stabilized soil at 180 d confirms the completed progress of prozzolanic reactions. The XRD diffractogram of the quicklime stabilized soil reveals the formation of both $\mathrm{C}-\mathrm{S}-\mathrm{H}\left(27.5^{\circ}\right.$ and $\left.52.9^{\circ}\right)$ and calcite $\left(13.1^{\circ}\right.$, $29.4^{\circ}$ and $36.0^{\circ}$ ). The formation of calcite is attributed to the air exposure of soil during the curing 
period and subsequent carbonation of quicklime and hydrated products (Verbrugge et al. 2011). The vulnerability of the quicklime stabilized soil to the carbonation, as compared to the CCR stabilized soil, primarily occurs at the early stage (Hunter 1988; Al-Mukhtar et al. 2012), during which quicklime stabilized soils develop relatively high porosity (which is demonstrated from the MIP test presented in the later section) and hence relatively large exposure area to carbon dioxide $\left(\mathrm{CO}_{2}\right)$ in the air.

\section{Thermogravimetric analysis}

Figure 7 shows the TGA and DTG results for the CCR and quicklime stabilized soils with 6\% content at 28 and $180 \mathrm{~d}$. The results of TGA are presented as a curve of the mass loss/first derivative of the mass loss versus temperature. Significant mass losses can be observed at a temperature of 50 to $200^{\circ} \mathrm{C}$ and 200 to $300^{\circ} \mathrm{C}$ from peaks in the DTG curves. The peaks in DTG curves (or mass losses in TGA curves) correspond to the presence of pozzolanic reaction products (C-S-H, C-A-H and C-A-S-H) during their thermal decompositions (HaHa et al. 2011). In addition, a sharp peak can be identified at the temperature of $425^{\circ} \mathrm{C}$, which is confirmed to be portlandite (HaHa et al. 2011). Since the pozzolanic reaction products (viz. C-S-H, C-A-H and C-A-S-H) have relatively low degree of crystallinity, their contents could not be calculated by the stoichiometric relation. In this study, the loss of hydroscopic water corresponding to the temperature of 50 to $200^{\circ} \mathrm{C}$ and 200 to $300^{\circ} \mathrm{C}$ was arbitrarily used to represent the content of C-S-H, and summed content of C-A-H and C-A-S-H, respectively. Table 7 shows the content of C-S-H and summed content of C-A-H and C-A-S-H in the soils tested. As seen in Table 7, the content of C-S-H and summed content of C-A-H and C-A-S-H increase with the increase in curing time. At both 28 and $120 \mathrm{~d}$, the content of C-S-H (1.861\% and $2.108 \%$ for 28 and 120 d, respectively) and summed content of C-A-H and 
401

402

403

404

405

406

407

408

409

410

411

412

413

414

415

416

417

418

419

420

421

422

423

C-A-S-H in the CCR stabilized soil $(0.95 \%$ and $1.01 \%$ for 28 and $120 \mathrm{~d}$, respectively) are higher than those in the quicklime stabilized soil $(1.804 \%$ and $1.98 \%(\mathrm{C}-\mathrm{S}-\mathrm{H}), 0.86 \%$ and $0.864 \%$ (sum of C-A-H and C-A-S-H) for 28 and 120 d, respectively). Figure 8 illustrates the correlations between $q_{\mathrm{u}}$ and summed content of $\mathrm{C}-\mathrm{S}-\mathrm{H}, \mathrm{C}-\mathrm{A}-\mathrm{H}$ and $\mathrm{C}-\mathrm{A}-\mathrm{S}-\mathrm{H}$ of the soils with $6 \%$ binder content. It is evident that higher summed content of C-S-H, C-A-H and C-A-S-H corresponds to higher $q_{\mathrm{u}}$ of the soils.

\section{Mercury intrusion porosimetry (MIP)}

Figure 9 presents the MIP results for the CCR and quicklime stabilized soils with $6 \%$ binder content, which are illustrated by the relations between cumulative pore volume and pore size. It is found that the total pore volumes decrease steadily with elapsed curing time for both CCR and quicklime stabilized soils. When the curing time increases from $28 \mathrm{~d}$ to $60 \mathrm{~d}$, the reductions of total pore volumes are $0.03 \mathrm{~mL} / \mathrm{g}$ and $0.08 \mathrm{~mL} / \mathrm{g}$ for CCR and quicklime stabilized samples, respectively.

The total pore volume for both CCR and quicklime stabilized soils, however, changes marginally from $60 \mathrm{~d}$ to $120 \mathrm{~d}$. Therefore, pore-filling by the pozzolanic products occurs primarily at the initial $60 \mathrm{~d}$ curing.

The CCR stabilized soil has a significantly smaller cumulative pore volume in all ranges of measured pore sizes (Fig. 9). Particularly, the total pore volume of the CCR stabilized soil is approximately $0.054 \mathrm{~mL} / \mathrm{g}$ lower than that of quicklime $(0.23 \mathrm{~mL} / \mathrm{g})$ at $28 \mathrm{~d}$. Nevertheless, the total pore volume is almost identical for both soils at $60 \mathrm{~d}$. At $120 \mathrm{~d}$ curing, the pore size distribution curves of both stabilized soils are well overlapped, indicating they have similar long-term porosimetry characteristics.

Figure 10 shows the pore volumes of different types of pores in the CCR and quicklime 
stabilized soils at different curing time. Horpibulsuk et al. (2009) reported that for the cement and fly-ash stabilized silty clays, pore diameters of 0.01 and $10 \mu \mathrm{m}$ are thresholds between intra-aggregate and inter-aggregate pores, and inter-aggregate and large air pores, respectively. It is found that the volumetric reduction in the large air pores with curing time, primarily, contributes to the reduction in the total pore volume for CCR and quicklime stabilized soils. The quicklime stabilized soil possesses greater volume of large air pores relative to the CCR stabilized soil regardless of the curing time. This coincides with the higher $q_{\mathrm{u}}$ value of the CCR stabilized soil over the quicklime stabilized soil. Previous studies also reported the similar relation between strength and volume of large pores in the soils. For example, Munkholm et al. (2002) found that tensile strength was conversely linearly correlated to the volume of pores with diameter $>30 \mu \mathrm{m}$ for sandy loam. Locat et al. (1996) found that the mechanical properties of lime stabilized inorganic clay were mainly controlled by the volume of pores with diameter $>0.01 \mu \mathrm{m}$.

\section{Discussion}

The results of this laboratory evaluation study demonstrate that the CCR stabilized clayey soil has superior mechanical performances than the quicklime stabilized soil. This advantage in mechanical performance can be interpreted from the physicochemical and microstructural points of view. At the early stage of curing, the binder-soil interaction is dominated by cation exchange (Hunter 1988). The cation exchange between the calcium ions from the hydration of CCR or quicklime and the readily exchangeable cations initially adsorbed on the clay particle results in a reduced thickness of diffusion double layer of clay particles, and formation of flocculation and agglomeration of soil particles as a consequence (Kinuthia et al. 1999; Saride et al. 2010). Finer particle size and larger specific surface area of the binder particles are preferable for the formation 
447

448

449

450

451

452

453

454

455

456

457

458

459

460

461

462

463

464

465

466

467

468

469

of flocculation and agglomeration (Kinuthia et al. 1999). Since the CCR has higher amount of fine particles and greater specific surface area relative to the quicklime (Table 3), flocculation and agglomeration of soil particles would be more notable in the CCR stabilized soil. This mechanism is substantiated by the analysis of particle size distribution of the stabilized soils, in which the particle size of the CCR stabilized soil is coarser than that of the quicklime stabilized soil at $28 \mathrm{~d}$ (Table 6).

The long-term interaction between the CCR or quicklime and soil is dominated by pozzolanic reactions (Hunter 1988). Portlandite reacts with the reactive $\mathrm{SiO}_{2} / \mathrm{Al}_{2} \mathrm{O}_{3}$ in soil matrix and produces pozzolanic products including C-S-H, C-A-H and C-A-S-H (Kinuthia et al. 1999; Al-Mukhtar et al. 2010). Finer particle size and larger specific surface area of the binder particle are more preferable for the implementation of reactions between portlandite and reactive $\mathrm{SiO}_{2} / \mathrm{Al}_{2} \mathrm{O}_{3}$ in the soil matrix. Therefore, higher amount of pozzolanic products is found to form in the CCR stabilize soil relative to the quicklime stabilized soil at the same curing time (Table 7).

The $\mathrm{pH}$ of the raw binder material also contributes to the different mechanical performances of the stabilized soils, since the pozzolanic reactions are controlled by the $\mathrm{pH}$ of binder-soil system and higher alkaline environment facilitates the dissolution of reactive $\mathrm{SiO}_{2} / \mathrm{Al}_{2} \mathrm{O}_{3}$ within clay minerals (Stronach and Glasser 1997; Saride et al. 2010). As the pH values of the CCR stabilized soil are higher than those of the quicklime stabilized soil (Fig. 5), the amendment of CCR to the parent soil would generate a faster dissolution rate of reactive $\mathrm{SiO}_{2} / \mathrm{Al}_{2} \mathrm{O}_{3}$ in the soil matrix and rate of pozzolanic reactions as a consequence. Because of the essential role of pozzolanic products in soil pore filling, soil particle bonding and soil strength development, a superior mechanical performance of the CCR stabilized soil over the quicklime stabilized soil is expected (Figs. 2 to 4 ).

In summary, it can be postulated that the variation in the physical and mechanical properties (Atterberg limits, particle size distribution, compaction characteristics, $q_{\mathrm{u}}, \mathrm{CBR}$, and $M_{\mathrm{r}}$ ) of the 
CCR stabilized soil could be identified by resorting to systematic investigations to detect changes in the physicochemical and microstructural characteristics via soil $\mathrm{pH}, \mathrm{XRD}$, TGA and MIP analyses. The superior mechanical performances for the CCR stabilized soil can be explained fundamentally from the basic properties of the binders and soil-binder interactions (flocculation/agglomeration and pozzolanic reactions). Furthermore, environmental impacts of the use of CCR in soil stabilization including leachability of heavy metals have been evaluated using batch-type leaching tests; the results demonstrated that CCR is an environmental-friendly binder (Du et al. 2015a). Further study is recommended for CCR stabilization of soils with entirely different properties (e.g., silty and sandy soils).

\section{Conclusions}

This study presents a multi-scale laboratory investigation of physical, mechanical and microstructural properties of CCR stabilized highway soft clayey soils, with a comparison with quicklime stabilized soils. The following conclusions can be drawn from this research:

(1) The stabilization by CCR or quicklime results in increase in the liquid limit and plastic limit while decease in the plasticity index. The addition of CCR or quicklime also leads to an increase in sand-sized particle percentage. Under the same curing period and binder content, the CCR stabilized soil attains higher sandy-sized particle percentage relative to the quicklime stabilized soil. The increase in the curing time and binder content facilitates larger $q_{\mathrm{u}}, \mathrm{CBR}$ and $M_{r}$. Under the same curing period, binder content and degree of compaction, the CCR stabilized soil exhibits superior mechanical performances relative to the quicklime stabilized soil.

(2) Both CCR and quicklime stabilized soils display a gradual reduction in soil $\mathrm{pH}$ with 

increased curing time, and $\mathrm{pH}$ of the CCR stabilized soil is always higher relative to the quicklime stabilized soil. Pozzolanic products like C-S-H, C-A-H and C-A-S-H are identified in both CCR and quicklime stabilized soils. The summed content of pozzolanic products in the CCR stabilized soil is higher than that in the quicklime stabilized soil. The CCR stabilized soil has a much smaller total pore volume than the quicklime stabilized soil within the initial $28 \mathrm{~d}$, though the difference is almost eliminated at $120 \mathrm{~d}$. The strength of the stabilized soil is found conversely correlated with the large pore volume in the soil.

(3) The fundamental mechanisms for the superior mechanical performances of the CCR stabilized soil over quicklime stabilized soil are the faster and more complete formation of flocculation and agglomeration of soil particles at the early stage as well as pozzolanic reactions within soils for the entire curing time. Finer particle size, greater specific area and higher $\mathrm{pH}$ value of $\mathrm{CCR}$ than quicklime are the essential contributors to the controlling mechanisms.

\section{Acknowledgements}

Financial support for this research was obtained from the National Natural Science Foundation of China (Grant No. 51278100, 41330641 and 41472258) and Natural Science Foundation of Jiangsu Province (Grant No. BK2012022). The fifth author is grateful to the Thailand Research Fund under the TRF Senior Research Scholar program Grant No. RTA5680002.

\section{References}

AASHTO 2007. Standard method of test for determining the resilient modulus of soils and aggregate materials. AASHTO T307-99, American Association of State Highway and 
517

518

519

520

521

522

523

524

525

526

527

528

529

530

531

532

533

534

535

536

537

Al-Mukhtar, M., Lasledj, A., Alcover, J.F. 2010. Behaviour and mineralogy changes in lime-treated expansive soil at $20{ }^{\circ} \mathrm{C}$. Applied Clay Science, 50 (2): 191-198. doi:10.1016/j.clay.2010.07.023

Al-Mukhtar, M., Khattab, S., and Alcover, J.F. 2012. Microstructure and geotechnical properties of lime-treated expansive clayey soil. Engineering Geology, 139-140: 17-27. doi:10.1016/j.enggeo.2012.04.004

Arulrajah, A., Disfani, M., Horpibulsuk, S., Suksiripattanapong, C. and Prongmanee, N. 2014. Physical properties and shear strength responses of recycled construction and demolition materials in unbound pavement base/subbase applications. Construction and Building Materials. 58: 245-257. doi:10.1016/j.conbuildmat.2014.02.025

ASTM 2008. Standard test method for unconfined compressive strength index of chemical- grouted soils. ASTM D4219-08, American Society for Testing and Materials, West Conshohocken, USA.

ASTM 2010. Standard test methods for liquid limit, plastic limit, and plasticity index of soils. ASTM D4318-10, American Society for Testing and Materials, West Conshohocken, USA.

ASTM 2011a. Standard practice for classification of soils for engineering purposes (unified soil classification system). ASTM D2487-11, American Society for Testing and Materials, West Conshohocken, USA.

ASTM 2011b. Standard terminology relating to lime and limestone (as used by the industry). ASTM C51-11, American Society for Testing and Materials, West Conshohocken, USA.

ASTM 2012. Standard test methods for laboratory compaction characteristics of soil using standard effort (12 $\left.400 \mathrm{ft}-\mathrm{lbf} / \mathrm{ft}^{3}\left(600 \mathrm{kN}-\mathrm{m} / \mathrm{m}^{3}\right)\right)$. ASTM D698-12, American Society for Testing and 


\section{Material, West Conshohocken, USA.}

ASTM 2013. Standard test method for pH of soils. ASTM D4972-13, American Society for Testing and Material, West Conshohocken, USA.

ASTM 2014. Standard test method for California Bearing Ratio (CBR) of laboratory-compacted soils. ASTM D1883-14, American Society for Testing and Material, West Conshohocken, USA.

Bell, F.G. 1996. Lime stabilization of clay minerals and soils. Engineering Geology, 42(4): 223-237. doi:10.1016/0013-7952(96)00028-2

Cai, G.H., Du, Y.J., Liu, S.Y., Singh, D.N. 2015. Physical properties, electrical resistivity and strength characteristics of carbonated silty soil admixed with reactive magnesia. Canadian Geotechnical Journal. doi: 10.1139/cgj-2015-0053

Chakrabarti, S. and Kodikara, J.K. 2007. Direct tensile failure of cementitiously stabilised crushed rock materials. Canadian Geotechnical Journal, 44(2): 231-240. doi: 10.1139/t06-102

China MOT. 2004. Specifications for Design of Highway Subgrades. China Ministry of Transportation, JTG D30-2004, Beijing, China.

Diamond, S. 1970. Pore size distributions in clays. Clays and Clay Minerals., 18: 7-23.

Du, Y.J., Li, S.L., and Hayashi, S. 1999. Swelling-shrinkage properties and soil improvement of compacted expansive soil, Ning-Liang Highway, China. Engineering Geology, 53(3-4): 351-358. doi: 10.1016/S0013-7952(98)00086-6

Du, Y.J., Zhang, Y.Y., Liu, S.Y. 2011. Investigation of strength and california bearing ratio properties of natural soils treated by calcium carbide residues. In Proceedings of Geo-Frontiers 2011: Advances in Geotechnical Engineering, Dallas, Texas, 13-16 March 2011. American Society of Civil Engineers, Reston, USA, pp. 1237-1244. 
560

561

562

563

564

565

566

567

568

569

570

571

572

573

574

575

576

577

578

579

580

581

Du, Y.J., Jiang, N.J., Liu, S.Y., Jin, F., Singh, D.N., and Puppala, A.J. 2014a. Engineering properties and microstructural characteristics of cement stabilized zinc-contaminated kaolin. Canadian Geotechnical Journal, 51(3), 289-302. doi: 10.1139/cgj-2013-0177

Du, Y.J., Wei, M.L., Reddy, K.R., Jin, F., Wu H.L., and Liu, Z.P. 2014b. New phosphate-based binder for stabilization of soils contaminated with heavy metals: Leaching, strength and microstructure characterization. Journal of Environmental Management, 146: 179-188. doi: doi:10.1016/j.jenvman.2014.07.035

Du, Y.J., Jiang, N.J., Liu, S.Y., Horpibulsuk, S., and Arulrajah, A. 2015a. Full-scale field trial evaluating the performance of highway subgrade soil stabilized with calcium carbide residue. Soils and Foundations, under review.

Du, Y.J., Bo, Y.L., Jin, F., and Liu, C.Y. 2015b. Durability of reactive magnesia-activated slag-stabilized low plasticity clay subjected to drying-wetting cycle. European Journal of Environmental and Civil Engineering. doi: 10.1080/19648189.2015.1030088

Fahoum, K., Aggour, M.S., and Amini, F. 1996. Dynamic properties of cohesive soils treated with lime. Journal of Geotechnical Engineering, 122(5): 382-389. doi: 10.1061/(ASCE)0733-9410(1996)122:5(382)

Gnanendran, C.T., Piratheepan, J. 2010. Determination of fatigue life of a granular base material lightly stabilized with slag lime from indirect diametral tensile testing. Journal of Transportation Engineering, 136(8): 736-745. doi: 10.1061/(ASCE)TE.1943-5436.0000138

HaHa, M.B., Lothenbach, B., Saout, G.L., Winnefeld, F. 2011. Influence of slag chemistry on the hydration of alkali-activated blast-furnace slag - Part I: Effect of MgO. Cement and Concrete Research, 41(9): 955-963. doi:10.1016/j.cemconres.2011.05.002 
582

583

584

585

586

587

588

589

590

591

592

593

594

595

596

597

598

599

600

601

602

603

Han, J., Oztoprak, S., Parsons, R.L., and Huang, J. 2007. Numerical analysis of foundation columns to support widening of embankments. Computers and Geotechics, 34(6): 435-448. doi:10.1016/j.compgeo.2007.01.006

Horpibulsuk, S., Rachan, R., Raksachon, Y. 2009. Role of fly ash on strength and microstructure development in blended cement stabilized silty clay. Soils and Foundations, 49(1): 85-98.

Horpibulsuk, S., Phetchuay, C., and Chinkulkijniwat, A. 2012. Soil stabilization by calcium carbide residue and fly ash. Journal of Materials in Civil Engineering, 24(2): 184-193. doi: 10.1061/(ASCE)MT.1943-5533.0000370

Horpibulsuk, S., Phetchuay, C., Chinkulkijniwat, A., Cholaphatsorn, A. 2013a. Strength development in silty clay stabilized with calcium carbide residue and fly ash. Soils and Foundations, 53(4): 477-486. doi:10.1016/j.sandf.2013.06.001

Horpibulsuk, S., Chinkullijniwat, A., and Shen, S.L. 2013b. Engineering properties of recycled calcium carbide residue stabilized clay as fill and pavement materials. Construction and Building Materials, 46: 203-210. doi:10.1016/j.conbuildmat.2013.04.037

Hunter, D. 1988. Lime-induced heave in sulfate-bearing clay soils. Journal of Geotechnical Engineering, 114(2): 150-167. doi: 10.1061/(ASCE)0733-9410(1988)114:2(150)

Jaturapitakkul, C. and Roongreung, B. 2003. Cementing material from calcium carbide residue-rice husk ash. Journal of Materials in Civil Engineering, 15(5): 470-475. doi: 10.1061/(ASCE)0899-1561(2003)15:5(470)

Jin, F and Al-Tabbaa, A. 2014. Evaluation of novel reactive $\mathrm{MgO}$ activated slag binder for the immobilisation of lead and zinc. Chemosphere, 117: 285-294. doi:10.1016/j.chemosphere.2014.07.027 
604 Kinuthia, J.M, Wild, S., Jones, G.I. 1999. Effects of monovalent and divalent metal sulphates on 605 consistency and compaction of lime-stabilised kaolinite. Applied Clay Science, 14 (1-3): 27-45. doi:10.1016/S0169-1317(98)00046-5

607

608

609

610

611

612

613

614

615

616

617

618

619

620

621

622

623

624

625

Kodikara, J.K. and Chakrabarti, S. 2005. Modelling of moisture loss in cementitiously stabilised pavement materials. International Journal of Geomechanics, 5(4): 295-303. doi: 10.1061/(ASCE)1532-3641(2005)5:4(295)

Krammart, P., Tangtermsirikul, S. 2004. Properties of cement made by partially replacing cement raw materials with municipal solid waste ashes and calcium carbide waste. Construction and Building Materials, 18(8): 579-583. doi:10.1016/j.conbuildmat.2004.04.014

Kampala, A. and Horpibulsuk, S. 2013. Engineering properties of silty clay stabilized with calcium carbide residue. Journal of Materials in Civil Engineering, 25(5): 632-644. doi: 10.1061/(ASCE)MT.1943-5533.0000618

Kampala, A., Horpibulsuk, S., Chinkulkijniwat, A. and Shen, S.L. 2013. Engineering properties of recycled calcium carbide residue stabilized clay as fill and pavement materials. Construction and Building Materials, 46: 203-210. doi:10.1016/j.conbuildmat.2013.04.037

Lemaire K., Deneele, D., Bonnet, S., and Legret, M. 2013. Effects of lime and cement treatment on the physicochemical, microstructural and mechanical characteristics of a plastic silt. Engineering Geology, 166: 255-261. doi:10.1016/j.enggeo.2013.09.012

Le Runigo, B., Cuisinier, O., Cui, Y.-J., Ferber, V., Deneele, D. 2009. Impact of initial state on the fabric and permeability of a lime-treated silt under long-term leaching. Canadian Geotechnical Journal, 46 (11): 1243-1257. doi: 10.1139/T09-061

Liu, S.Y., Shao, G.H., Du, Y.J., and Cai, G.J. 2011. Depositional and geotechnical properties of 

marine clays in Lianyungang, China. Engineering Geology, 121(1-2): 66-74. doi:10.1016/j.enggeo.2011.04.014

Li, X., and Zhang, L.M. 2009. Characterization of dual-structure pore-size distribution of soil. Canadian Geotechnical Journal, 46(2): 129-141. doi: 10.1139/T08-110

Locat, J., Tremblay, H., Leroueil, S. 1996. Mechanical and hydraulic behavior of a soft inorganic clay treated with lime. Canadian Geotechnical Journal, 33(4): 654-669. doi: 10.1139/t96-090-311

Mitchell, J.K, and Soga, K. 2005. Fundamentals of soil behavior, John Wiley \& Sons, Hoboken, USA.

Mohammadinia, A., Arulrajah, A., Sanjayan, J., Disfani, M.M., Bo, M.W. and Darmawan, S. 2014. Laboratory evaluation of the use of cement-treated construction and demolition materials in pavement base/subbase applications. Journal of Materials in Civil Engineering, 04014186. doi: 10.1061/(ASCE)MT.1943-5533.0001148

Munkholm, L.J., Schjønning, P., and Kay, B.D. 2002. Tensile strength of soil cores in relation to aggregate strength, soil fragmentation and pore characteristics. Soil \& Tillage Research, 64, 125-135. doi:10.1016/S0167-1987(01)00250-1

Nalbantoglu, Z., and Tuncer, E.R. 2001. Compressibility and hydraulic conductivity of a chemically treated expansive clay. Canadian Geotechnical Journal, 38(1): 154-160. doi: 10.1139/t00-076

Osinubi, K. 1998. Influence of compactive efforts and compaction delays on lime-treated soil. Journal of Transportation Engineering, 124(2): 149-155. doi: 10.1061/(ASCE)0733-947X(1998)124:2(149)

Penumadu, D., and Dean, J. 2000. Compressibility effect in evaluating the pore-size distribution of 28 
648

649

650

651

652

653

654

655

656

657

658

659

660

661

662

663

664

665

666

667

668

669

kaolin clay using mercury intrusion porosimetry. Canadian Geotechnical Journal, 37(2): 393-405. doi: 10.1139/t99-121

Phetchuay, C., Horpibulsuk, S., Suksiripattanapong, C., Chinkulkijniwat, A., Arulrajah, A., and Disfani, M.M. 2014. Calcium carbide residue: Alkaline activator for clay-fly ash geopolymer. Construction and Building Materials, 69: 285-294. doi:10.1016/j.conbuildmat.2014.07.018

Saride, S., Puppala, A.J., and Chikyala, S.R. 2010. Swell-shrink and strength behaviors of lime and cement stabilized expansive organic clays. Applied Clay Science, 85: 155-164. doi:10.1016/j.clay.2013.09.008

Sharma, H.D., Reddy, K.R., 2004. Geoenvironmental engineering: site remediation, waste containment, and emerging waste management technologies. John Wiley \& Sons, Inc, Hoboken, New Jersey.

Shen, S.L., Wang, Z., Yang, J., and Ho, C. 2013. Generalized approach for prediction of jet grout column diameter. Journal of Geotechnical and Geoenvironmental Engineering, 139(12): 2060-2069. doi:10.1061/(ASCE)GT.1943-5606.0000932

Stoltz, G., Cuisinier, O., and Masrouri, F. 2012. Multi-scale analysis of the swelling and shrinkage of a lime-treated expansive clayey soil. Applied Clay Science, 61: 44-51. doi:10.1016/j.clay.2012.04.001

Stronach, S.A., and Glasser, F.P. 1997. Modelling the impact of abundant geochemical components on phase stability and solubility of the $\mathrm{CaO}-\mathrm{SiO}_{2}-\mathrm{H}_{2} \mathrm{O}$ system at $25^{\circ} \mathrm{C}: \mathrm{Na}^{+}, \mathrm{K}^{+}, \mathrm{SO}_{4}{ }^{2-}, \mathrm{Cl}^{-}$and $\mathrm{CO}_{3}{ }^{2-}$. Advances in Cement Research, 9(36): 167-181. doi:10.1680/adcr.1997.9.36.167

Sukmak, P., Horpibulsuk, S. and Shen, S.L. 2013a. Strength development in clay-fly ash geopolymer. Construction and Building Materials,

40: 566-574. doi: 
671

672

673

674

675

676

677

678

679

680

681

682

683

684

685

686

687

688

689

690

691

692

Sukmak, P., Horpibulsuk, S., Shen, S.L., Chindaprasirt, P., and Suksiripattanpong, C. 2013 b. Factors influencing strength development in clay-fly ash geopolymer. Construction and Building Materials, 47: 1125-1136. doi:10.1016/j.conbuildmat.2013.05.104

Sukmak, P., Silva, P.D., Horpibulsuk, S. and Chindaprasirt, P. 2015. Sulfate resistance of clay-Portland cement and clay-high calcium fly ash geopolymer. Journal of Materials in Civil Engineering, 27(5): 04014158. 10.1061/(ASCE)MT.1943-5533.0001112

Tastan, E.O., Edil, T.B., Benson, C.H., and Aydilek, A.H. 2011. Stabilization of organic soils with fly ash. Journal of Geotechnical and Geoenvironmental Engineering, 137(9): 819-833. doi: 10.1061/(ASCE)GT.1943-5606.0000502

Tran, T.D., Cui, Y,J., Tang, A.M., Audiguier, M., and Cojean, R. 2014. Effects of lime treatment on the microstructure and hydraulic conductivity of Héricourt clay. Journal of Rock Mechanics and Geotechnical Engineering, 6: 399-404. doi:10.1016/j.jrmge.2014.07.001

Verbrugge, J., De Bel, R., Correia, A., Duvigneaud, P., and Herrier, G. 2011. Strength and micro observations on a lime treated silty soil. In Proceedings of GeoHunan 2011: Road Materials and New Innovations in Pavement Engineering. Hunan China, 9-11 June 2011. American Society of Civil Engineers, Reston, USA, pp. 89-96.

Vichan, S. and Rachan, R. 2013. Chemical stabilization of soft Bangkok clay using the blend of calcium carbide residue and biomass ash. Soils and Foundations, 53(2): 272-281. doi: 10.1016/j.sandf.2013.02.007

Wild, S., Abdi, M. R., and Leng-Ward, G. 1993. Sulphate expansion of lime-stabilized kaolinite: ii. reaction products and expansion. Clay Minerals, 28: 569-583. 
693 Table 1. Properties of soils tested

\begin{tabular}{|c|c|}
\hline Index & Value \\
\hline Natural moisture content, $w_{n}(\%)$ & 29.4 \\
\hline Specific gravity, $G_{s}$ & 2.73 \\
\hline Liquid limit, $w_{\mathrm{L}}(\%)^{\mathrm{a}}$ & 37.8 \\
\hline Plastic limit, $w_{\mathrm{P}}(\%)^{\mathrm{a}}$ & 19.9 \\
\hline Maximum dry density, $\rho_{d, \max }\left(\mathrm{g} / \mathrm{cm}^{3}\right)^{\mathrm{b}}$ & 1.92 \\
\hline Optimum moisture content, $w_{\text {opt }}(\%)^{\mathrm{b}}$ & 13.5 \\
\hline \multicolumn{2}{|l|}{ Particle size distribution $(\%)^{\mathrm{c}}$} \\
\hline Clay $(<0.002 \mathrm{~mm})$ & 13.6 \\
\hline Silt $(0.002$ to $0.074 \mathrm{~mm})$ & 83.9 \\
\hline Sand $(>0.074 \mathrm{~mm})$ & 2.5 \\
\hline
\end{tabular}

$694{ }^{\mathrm{a}}$ Based on ASTM D4318 (ASTM, 2010).

$695{ }^{\mathrm{b}}$ Based on ASTM D698 (ASTM, 2012).

$696{ }^{c}$ Measured using a laser particle size analyzer Mastersizer 2000

697

698

699

700 
701 Table 2. Major chemical compositions of the parent soil, CCR and quicklime used in this study ${ }^{\text {a }}$

\begin{tabular}{cccc}
\hline Chemical composition & Soil (\%) & CCR (\%) & Quicklime (\%) \\
\hline $\mathrm{CaO}$ & 1.3 & 68.99 & 68.54 \\
$\mathrm{SiO}_{2}$ & 67.9 & 2.84 & 2.54 \\
$\mathrm{Al}_{2} \mathrm{O}_{3}$ & 14.1 & 2.16 & 1.0 \\
$\mathrm{MgO}$ & 2.5 & 0.12 & 0.34 \\
$\mathrm{Fe}_{2} \mathrm{O}_{3}$ & 5.0 & 0.15 & 0.62 \\
$\mathrm{SO}_{3}$ & 0.01 & 0.76 & 0.11 \\
Loss of ignition & 5.19 & 24.85 & 26.51 \\
\hline
\end{tabular}

702

${ }^{\mathrm{a}}$ Measured using a X-ray Fluorescence Spectrometer.

703

704

705 
706 Table 3. Basic physical and chemical properties of CCR and quicklime

\begin{tabular}{lcc}
\hline \multicolumn{1}{c}{ Index } & CCR & Quicklime \\
\hline Specific gravity, $G_{s}$ & 2.32 & 3.21 \\
${\text { Specific surface area }\left(\mathrm{m}^{2} / \mathrm{g}\right)^{\text {a }}}$ & 24.664 & 5.020 \\
$\mathrm{pH}^{\mathrm{b}}$ & 12.84 & 12.74 \\
${\text { Particle size distribution }(\%)^{\mathrm{c}}}$ & & \\
Clay $(<0.002 \mathrm{~mm})$ & 4.2 & 3.9 \\
Silt $(0.002$ to $0.074 \mathrm{~mm})$ & 67.6 & 37.8 \\
Sand $(>0.074 \mathrm{~mm})$ & 28.2 & 58.3 \\
\hline
\end{tabular}

$707{ }^{\mathrm{a}}$ Measured using a Quantachrome Autosorb-iQ-AG automated gas sorption analyzer.

$708{ }^{\mathrm{b}}$ Based on ASTM 4972 (ASTM, 2013).

$709{ }^{\mathrm{c}}$ Measured using a laser particle size analyzer Mastersizer 2000. 
710 Table 4. Summary of binder dosage, curing time, degree of compaction and number of 711 identical samples for different tests in this study

\begin{tabular}{ccccc}
\hline Testing program & $\begin{array}{c}\text { Binder } \\
\text { dosage } \\
(\%)\end{array}$ & $\begin{array}{c}\text { Curing time } \\
(\text { day })\end{array}$ & $\begin{array}{c}\text { Degree of } \\
\text { compaction } \\
(\%)\end{array}$ & $\begin{array}{c}\text { Number of } \\
\text { identical } \\
\text { samples }\end{array}$ \\
\hline $\begin{array}{c}\text { Atterberg limits } \\
\text { PSD }^{\mathrm{a}}\end{array}$ & $0,4,6$ & 28 & $\mathrm{NA}^{\mathrm{h}}$ & 1 \\
Compaction $^{\mathrm{h}}$ & $0,4,6$ & 28 & $\mathrm{NA}^{\mathrm{h}}$ & 1 \\
$\mathrm{UCS}^{\mathrm{b}}$ & $0,4,6$ & 0 & $\mathrm{NA}^{\mathrm{h}}$ & 1 \\
CBR $^{\mathrm{c}}$ & $0,4,6$ & $7,28,60,120$ & $93,94,96$ & 3 \\
$M_{r}{ }^{\mathrm{h}}$ & $0,4,6$ & 7,28 & $93,94,96$ & 3 \\
Soil pH $^{\mathrm{d}}$ & 6 & $7,28,60,120$ & 94,96 & 3 \\
XRD $^{\mathrm{e}}$ & 0,6 & 180 & 100 & 1 \\
TGA $^{\mathrm{f}}$ & 6 & 28,120 & 100 & 1 \\
MIP $^{\mathrm{g}}$ & 6 & $28,60,120$ & 100 & 3 \\
\hline
\end{tabular}

\footnotetext{
$712{ }^{\mathrm{a}}$ Particle size distribution

$713{ }^{\mathrm{b}}$ Unconfined compressive strength (UCS)

$714{ }^{\mathrm{c}}$ California Bearing ratio (CBR)

$715{ }^{\mathrm{d}}$ Resilient modulus

$716{ }^{\mathrm{e}} \mathrm{X}$-ray diffraction (XRD)

$717{ }^{\mathrm{f}}$ Thermogravimetric analyses (TGA)

$718{ }^{\mathrm{g}}$ Mercury intrusion porosimetry (MIP)

$719{ }^{\mathrm{h}}$ Not available

720

721

722

723

724
} 
725 Table 5. Results of Atterberg limits tests for CCR and quicklime stabilized and unstabilized 726 soils

\begin{tabular}{cccccc}
\hline Soil & $\begin{array}{c}\text { Binder } \\
\text { content }(\%)\end{array}$ & $\begin{array}{c}\text { Curing } \\
\text { time }(\mathrm{d})\end{array}$ & $\begin{array}{c}\text { Liquid limit, } \\
w_{\mathrm{L}}(\%)\end{array}$ & $\begin{array}{c}\text { Plastic limit, } \\
w_{\mathrm{p}}(\%)\end{array}$ & $\begin{array}{c}\text { Plastic } \\
\text { index, } I_{p}\end{array}$ \\
\hline Untreated soil & 0 & $\mathrm{NA}^{\mathrm{a}}$ & 37.8 & 19.9 & 17.9 \\
\hline $\begin{array}{c}\text { CCR stabilized } \\
\text { soils }\end{array}$ & 4 & 28 & 42.7 & 29.6 & 13.1 \\
\cline { 2 - 6 } & 6 & 28 & 39.8 & 26.4 & 13.4 \\
\hline $\begin{array}{c}\text { Quicklime } \\
\text { stabilized soils }\end{array}$ & 4 & 28 & 41.6 & 26.8 & 14.8 \\
\cline { 2 - 6 } & 6 & 28 & 44.3 & 28.8 & 15.5 \\
\hline
\end{tabular}

$727{ }^{\mathrm{a}}$ Not available 
728 Table 6. Results of particle size distribution test

\begin{tabular}{cccccc}
\hline Soil & $\begin{array}{c}\text { Binder } \\
\text { content } \\
(\%)\end{array}$ & $\begin{array}{c}\text { Curing } \\
\text { time }(\mathrm{d})\end{array}$ & $\begin{array}{c}\text { Clay-sized } \\
\text { particle }(<2 \\
\mu \mathrm{m})(\%)\end{array}$ & $\begin{array}{c}\text { Silt-sized } \\
\text { particle }(2 \text { to } \\
74 \mu \mathrm{m})(\%)\end{array}$ & $\begin{array}{c}\text { Sand-sized } \\
\text { particle }(74 \text { to } \\
2000 \mu \mathrm{m})(\%)\end{array}$ \\
\hline $\begin{array}{c}\text { Unstabilized } \\
\text { soil }\end{array}$ & 0 & $\begin{array}{c}\text { Not } \\
\text { available }\end{array}$ & 13.6 & 83.9 & 2.5 \\
\hline $\begin{array}{c}\text { CCR stabilized } \\
\text { soil }\end{array}$ & 4 & 28 & 7.1 & 55.1 & 37.8 \\
\cline { 2 - 6 } & 6 & 28 & 3.8 & 35.5 & 60.7 \\
\hline $\begin{array}{c}\text { Quicklime } \\
\text { stabilized soil }\end{array}$ & 4 & 28 & 10.0 & 63.6 & 26.4 \\
\cline { 2 - 6 } & 6 & 28 & 8.2 & 65.2 & 26.6 \\
\hline
\end{tabular}

729

730 
731 Table 7. The relative content of the hydration products

\begin{tabular}{ccccccc}
\hline \multirow{2}{*}{$\begin{array}{c}\text { Hydration } \\
\text { product }\end{array}$} & Range of & \multicolumn{2}{c}{ CCR } & \multicolumn{2}{c}{ Quicklime } & \\
& water loss & \multicolumn{2}{c}{$(\%)$} & \multicolumn{2}{c}{$(\%)$} & Reference \\
\cline { 3 - 6 } & $\left({ }^{\circ} \mathrm{C}\right)$ & $28 \mathrm{~d}$ & $120 \mathrm{~d}$ & $28 \mathrm{~d}$ & $120 \mathrm{~d}$ & \\
\hline $\mathrm{CSH}$ & 50 to 200 & 1.861 & 2.108 & 1.804 & 1.98 & HaHa et al. (2011) \\
CAH+CASH & 200 to 300 & 0.95 & 1.01 & 0.86 & 0.864 & HaHa et al. (2011) \\
\hline
\end{tabular}

732

733 


\section{List of Figure captions}

735

736 Fig. 1 Particle size distributions of unstabilized soil, CCR and quicklime.

737 Fig. 2 Variations of $q_{\mathrm{u}}$ with curing time for soils with various degree of compaction: (a) 93\%;

738

(b) $94 \%$; and (c) $96 \%$.

739 Fig. 3 Variations of CBR with curing time and binder content for soils with various degree of 740 compaction: (a) 93\%; (b) 94\%; and (c) $96 \%$.

741 Fig. 4 Variations of resilient modulus $\left(M_{\mathrm{r}}\right)$ with degree of compaction and curing time for 742 unstabilized soils and soils of $6 \%$ binder.

$743 \quad$ Fig. 5 Variations of soil $\mathrm{pH}$ with curing time.

744 Fig. 6 XRD diffractograms of unstabilized soil and CCR and quicklime stabilized soils.

745 Fig. 7 Thermogravimetric analysis (TGA) and differential thermogravimetric (DTG) analysis 746 of soils stabilized with: (a) CCR at $28 \mathrm{~d}$; (b) quicklime at $28 \mathrm{~d}$; (c) CCR at $120 \mathrm{~d}$; and (d) 747 quicklime at $120 \mathrm{~d}$.

748 Fig. 8 Summed content of C-S-H, C-A-H and C-A-S-H versus $q_{\mathrm{u}}$ of soils stabilized with CCR 749 and quicklime (6\% binder content).

750 Fig. 9 MIP test results for CCR and quicklime stabilized soils.

751 Fig. 10 Distributions of different types of pores in CCR and quicklime stabilized soils. 752 


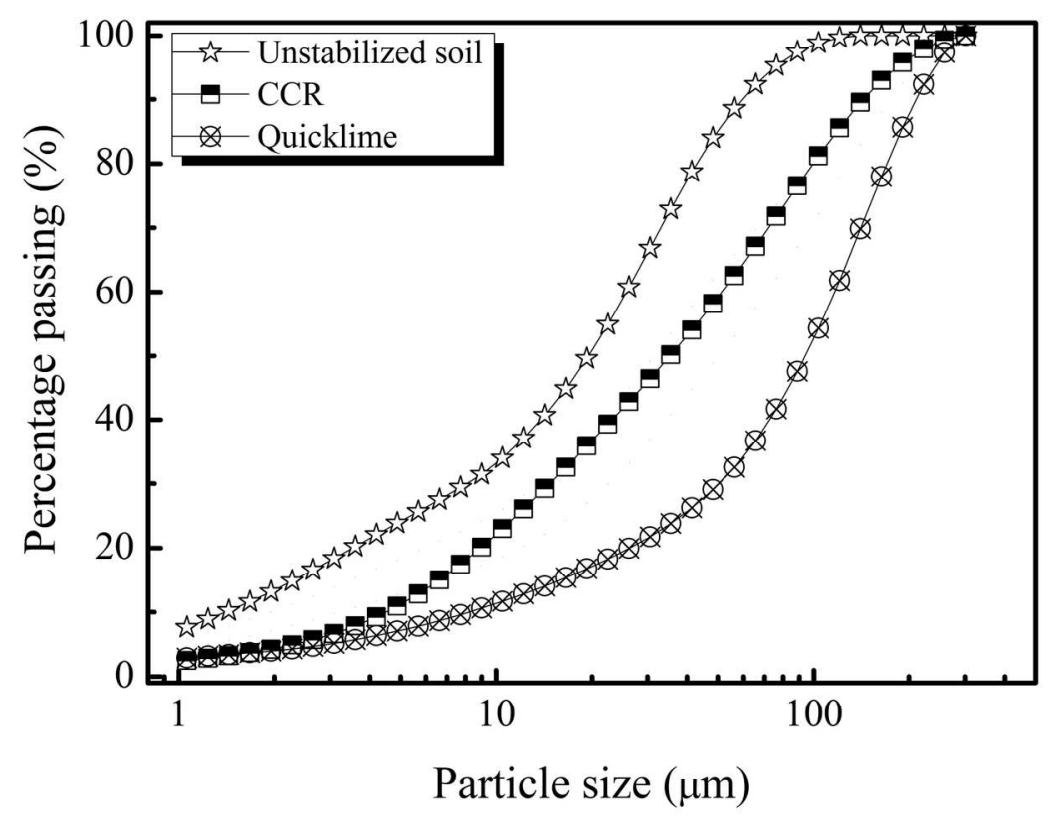

Fig. 1 Particle size distributions of unstabilized soil, CCR and quicklime. $172 \times 122 \mathrm{~mm}(300 \times 300 \mathrm{DPI})$ 

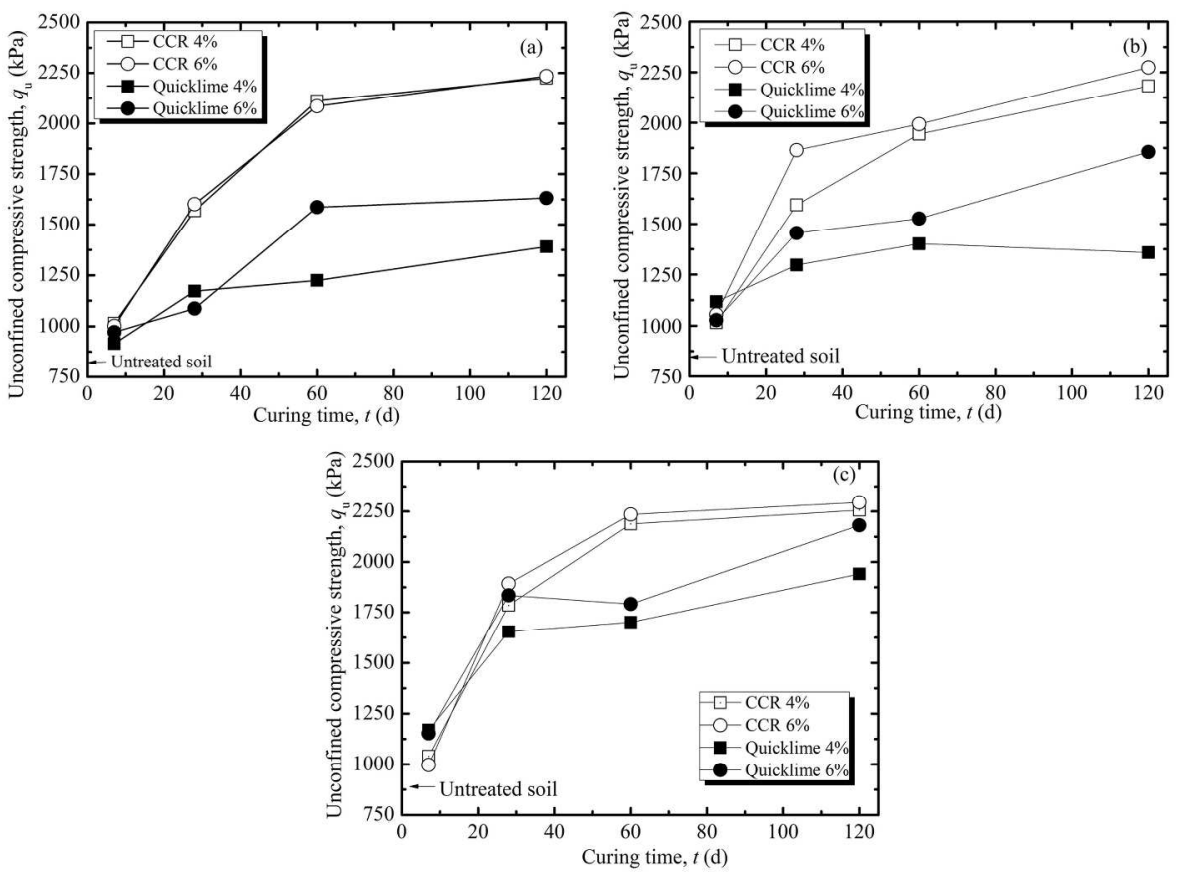

Fig. 2 Variations of qu with curing time for soils with various degree of compaction: (a) $93 \%$; (b) $94 \%$; and (c) $96 \%$.

$203 \times 146 \mathrm{~mm}(300 \times 300 \mathrm{DPI})$ 

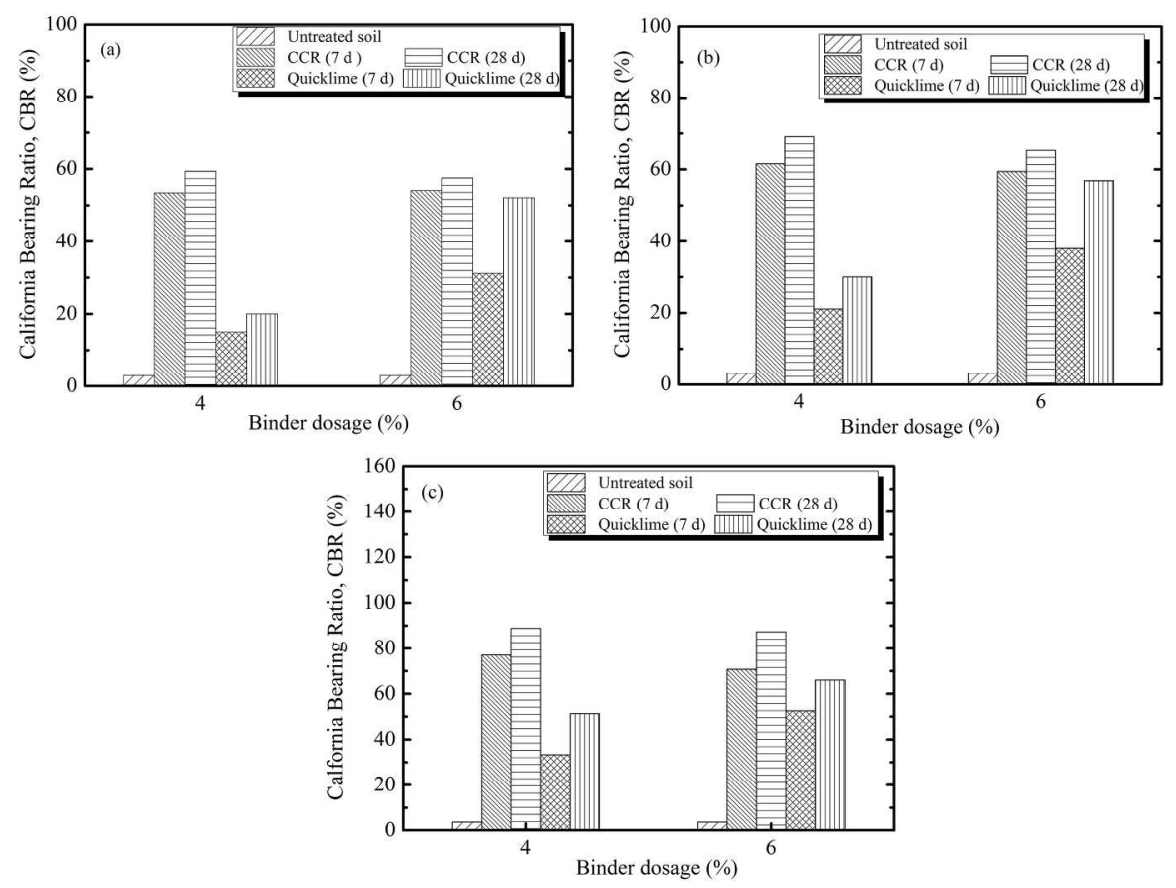

Fig. 3 Variations of CBR with curing time and binder content for soils with various degree of compaction: (a) 93\%; (b) $94 \%$; and (c) $96 \%$.

$214 \times 156 \mathrm{~mm}(300 \times 300 \mathrm{DPI})$ 


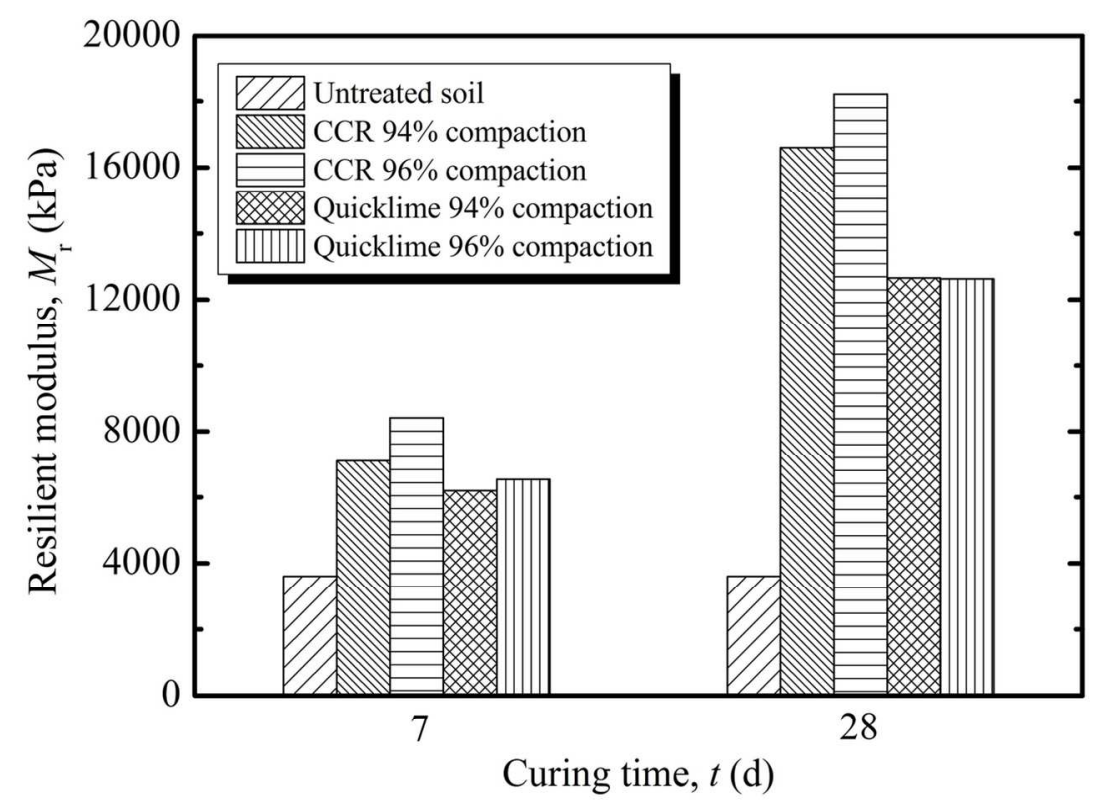

Fig. 4 Variations of resilient modulus (Mr) with degree of compaction and curing time for unstabilized soils and soils of $6 \%$ binder. $131 \times 92 \mathrm{~mm}$ (300 x 300 DPI) 


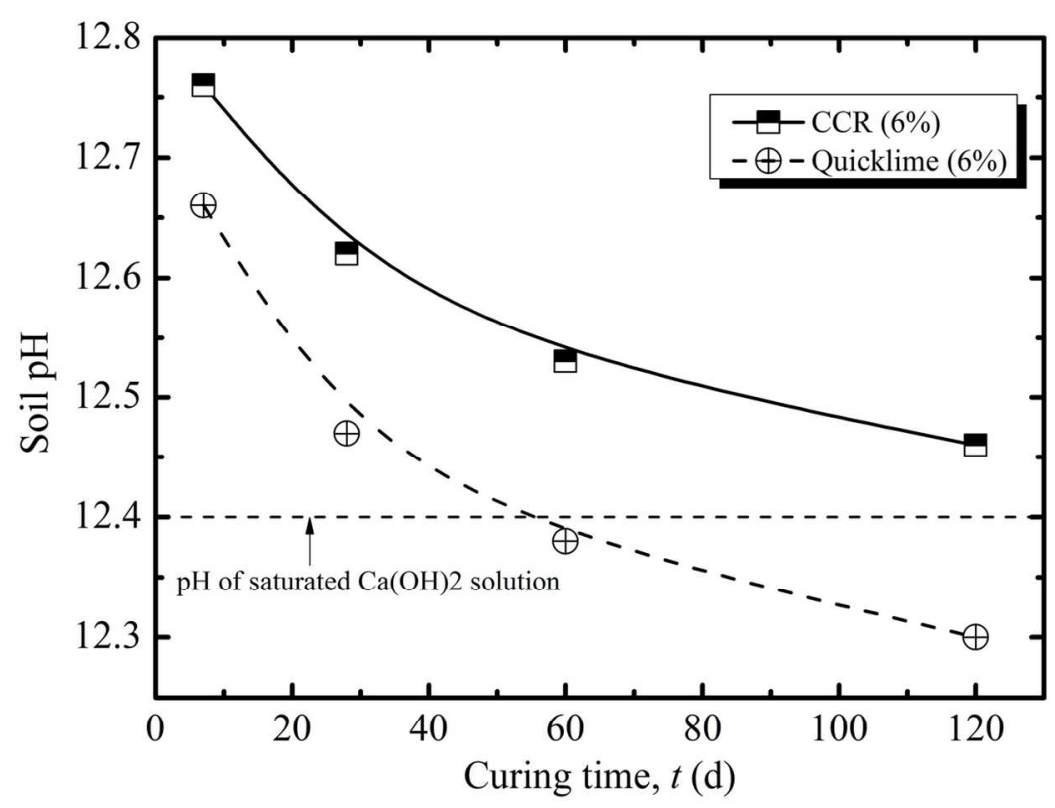

Fig. 5 Variations of soil pH with curing time. $135 \times 95 \mathrm{~mm}(300 \times 300 \mathrm{DPI})$ 


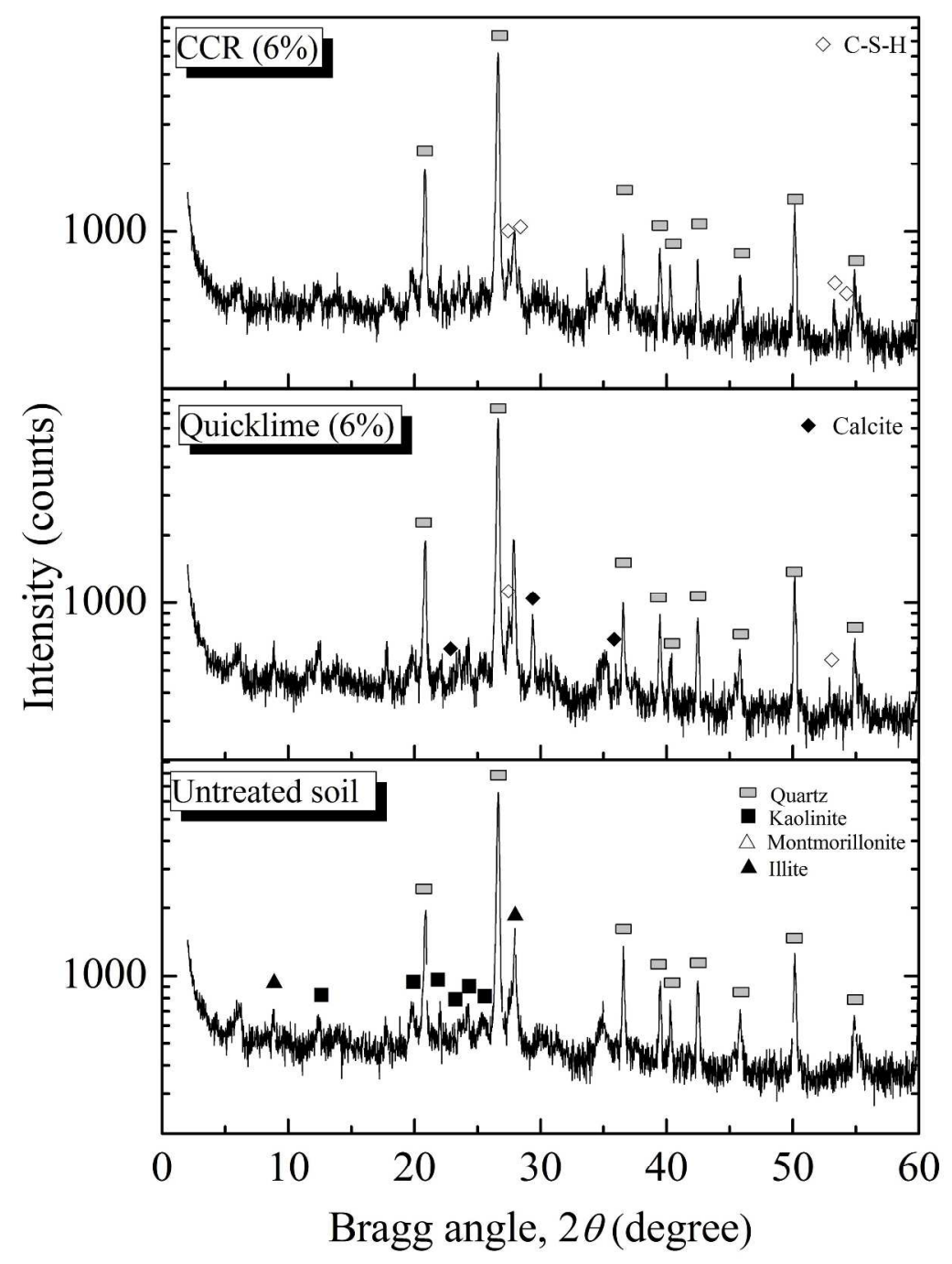

Fig. 6 XRD diffractograms of unstabilized soil and CCR and quicklime stabilized soils. $251 \times 356 \mathrm{~mm}(300 \times 300$ DPI) 

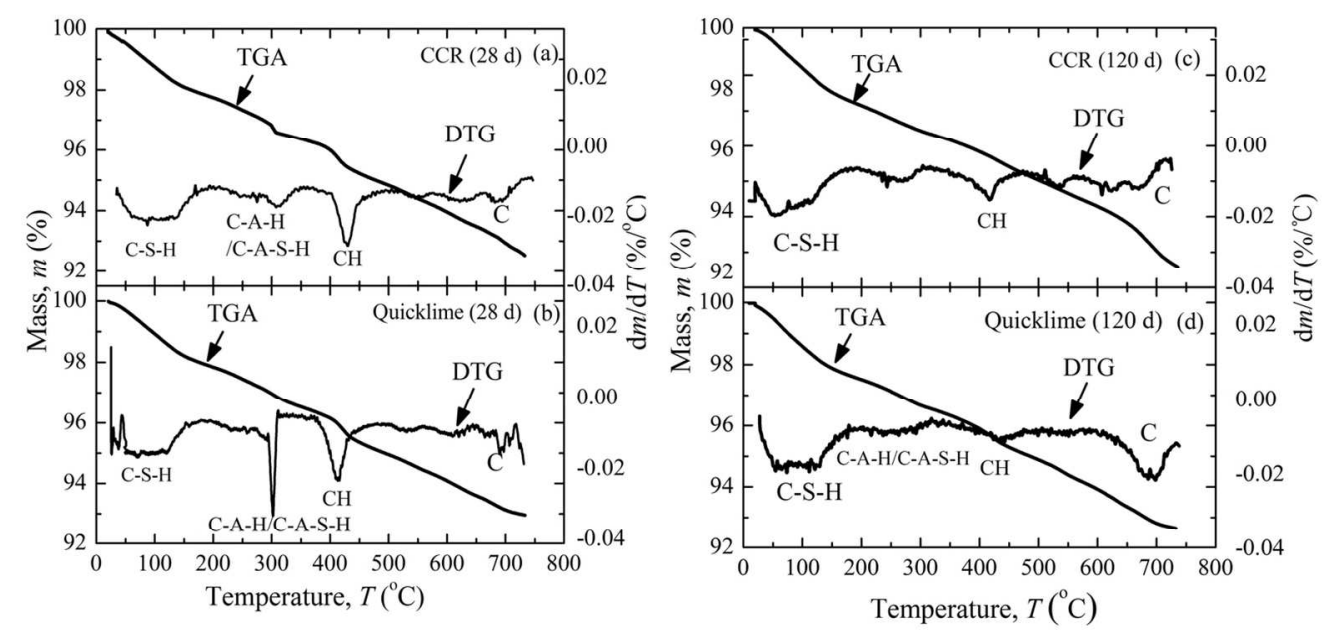

Fig. 7 Thermogravimetric analysis (TGA) and differential thermogravimetric (DTG) analysis of soils stabilized with: (a) CCR at $28 \mathrm{~d}$; (b) quicklime at $28 \mathrm{~d}$; (c) CCR at $120 \mathrm{~d}$; and (d) quicklime at $120 \mathrm{~d}$. $129 \times 64 \mathrm{~mm}(300 \times 300$ DPI $)$ 


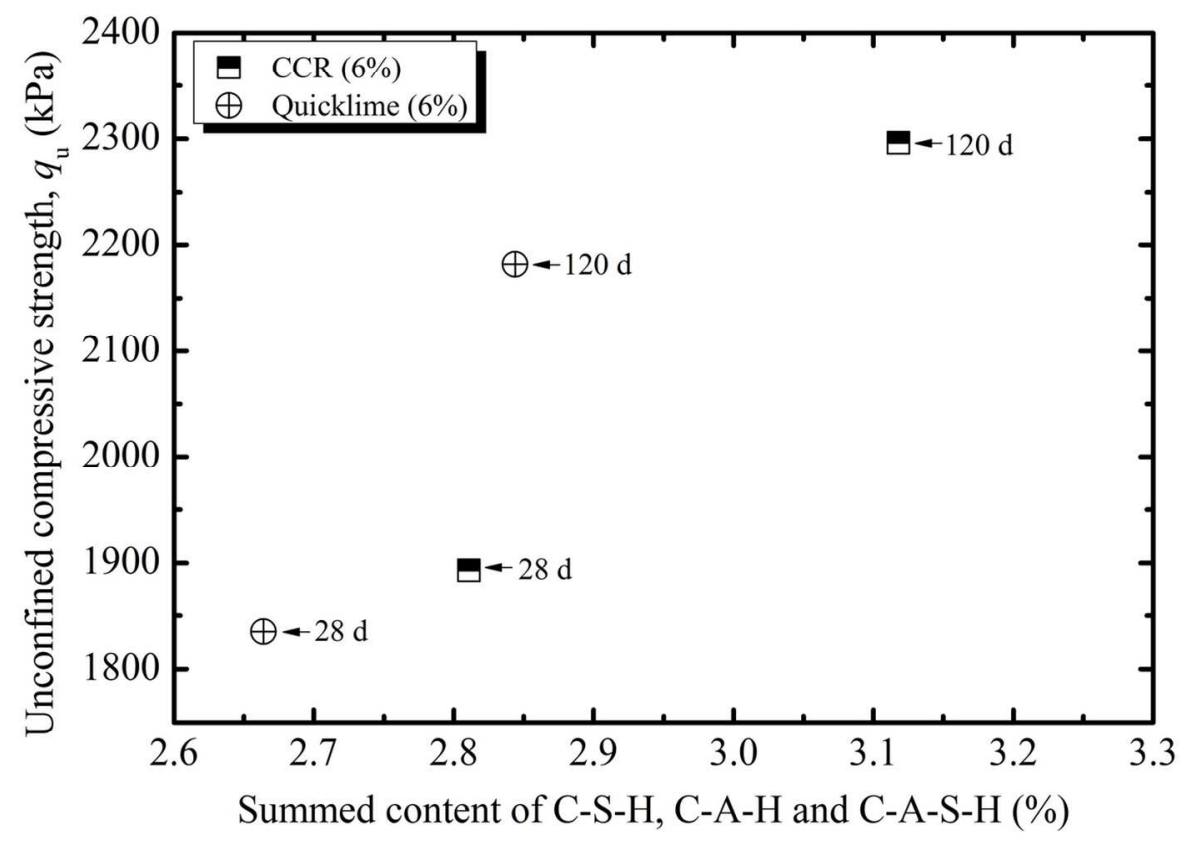

Fig. 8 Summed content of C-S-H, C-A-H and C-A-S-H versus qu of soils stabilized with CCR and quicklime (6\% binder content). $128 \times 90 \mathrm{~mm}(300 \times 300 \mathrm{DPI})$ 


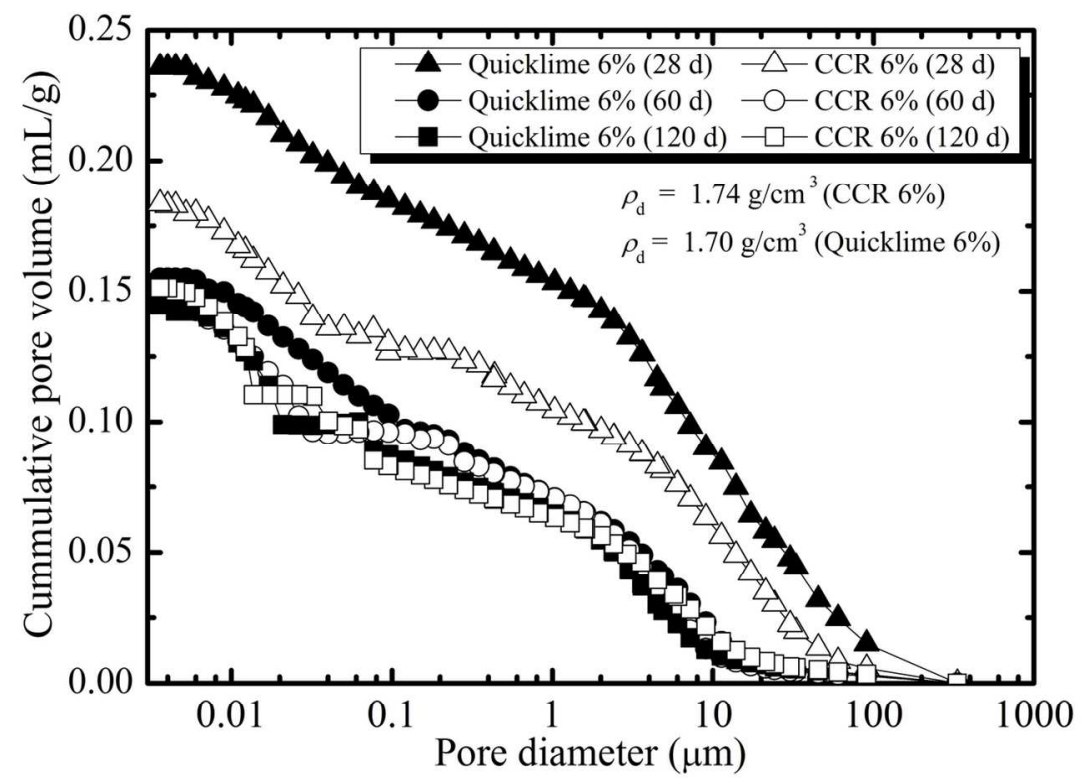

Fig. 9 MIP test results for CCR and quicklime stabilized soils. $137 \times 95 \mathrm{~mm}(300 \times 300 \mathrm{DPI})$ 


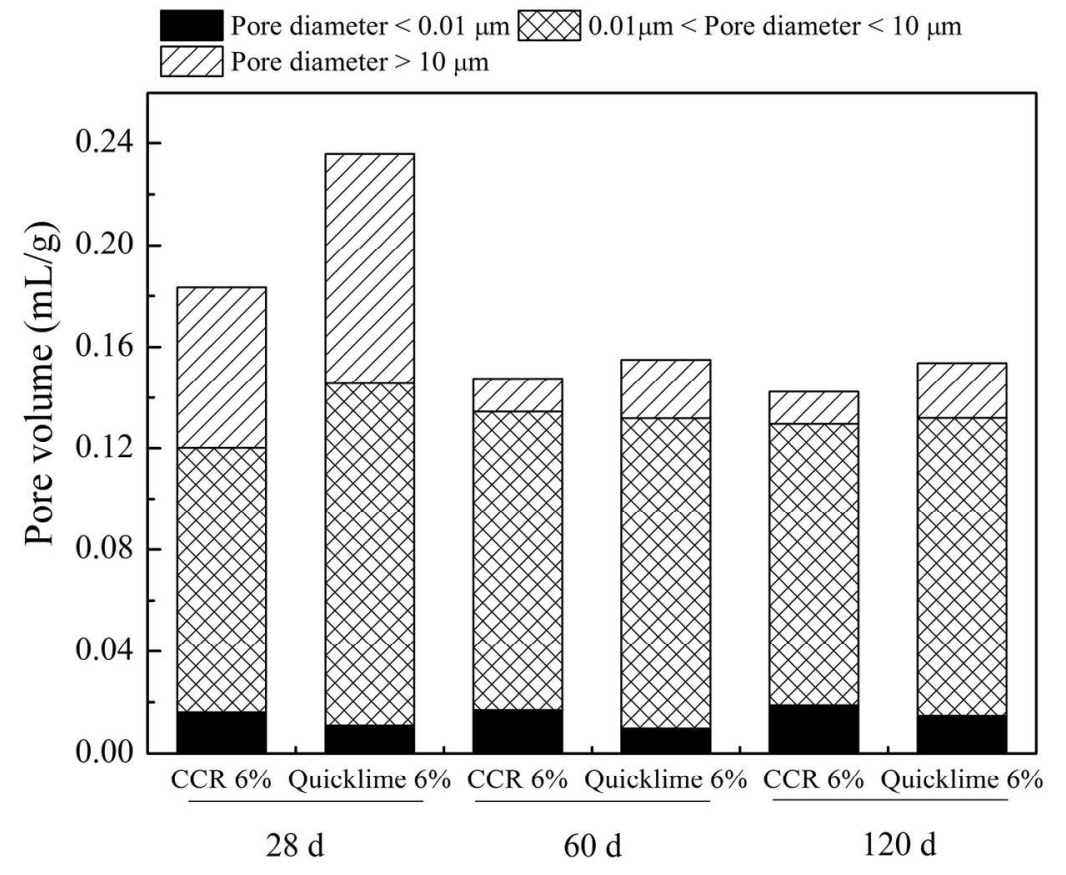

Fig. 10 Distributions of different types of pores in CCR and quicklime stabilized soils. $157 \times 111 \mathrm{~mm}(300 \times 300 \mathrm{DPI})$ 